TRANS · núm. 25·2021

DOSIER $\cdot 17-60$
Este artículo repasa los esfuerzos de traducción de las Escrituras realizados a lo largo del siglo XVI por las autoridades católicas hispanas y en el ámbito del castellano. Presenta una descripción de las dos grandes Biblias políglotas que contaron con el patrocinio de las más altas instancias la monarquía hispánica como ejemplo de los límites a los que podía llegar una ortodoxia que consideraba como texto auténtico la traducción latina hecha mil años antes por Jerónimo de Estridón; fueron dos importantes proyectos que, a pesar de ser multilingües, no trasladaron el texto bíblico a ninguna lengua vernácula. Fuera del amparo oficial (y aunque en algún momento, sobre todo en las primeras décadas del siglo, aún circularon algunas versiones parciales), las autoridades católicas (políticas y religiosas) alzaron enormes obstáculos a los intentos de traducción y difusión en lengua vulgar. Este trabajo ofrece un resumen de las principales versiones realizadas por católicos, judíos y protestantes, así como de la difusión y el alcance que tuvieron.

PALABRAS CLAVE: traducción bíblica, siglo XVI, cardenal Cisneros, Biblia políglota complutense, fray Luis de León, Benito Arias Montano, Biblia políglota de Amberes, Pentateuco de Constantinopla, Biblia de Ferrara, Juan de Valdés, Francisco de Enzinas, Juan Pérez de Pineda, Casiodoro de Reina, Biblia del Oso, Cipriano de Valera, Biblia del Cántaro, Biblia Reina-Valera, persecución religiosa, censura, diáspora judía, diáspora protestante.

\title{
Biblias políglotas y traducciones bíblicas al castellano en el siglo XVI
}

Juan Gabriel López Guix Universidad Autónoma de Barcelona

\section{Polyglot Bibles and Bible translations into Spanish in the $16^{\text {th }}$ century}

This article reviews the efforts at Scripture translation made throughout the 16th century by the Hispanic authorities and by translators determined to produce a Spanish version of the Bible. It presents a description of the two great polyglot Bibles that enjoyed the patronage of the highest authorities of the Hispanic monarchy. Both projects illustrate the limits to which an orthodoxy that considered Jerome's thousand-year-old Latin translation as the authentic biblical text could go. Formidable as these projects were, and despite being multilingual, they did not translate the biblical text into any vernacular language. Outside the official protection (and although at some point, especially in the early decades of the century, some partial versions still circulated), the Catholic (political and religious) authorities raised enormous obstacles to the attempts at translation and dissemination in the vernacular. This article offers a summary of the main versions produced by Catholics, Jews and Protestants, as well as their spread and scope.

KEY WORDS: Bible translation, $16^{\text {th }}$ century, Cardinal Cisneros, Complutensian Polyglot Bible, Fray Luis de León, Benito Arias Montano, Antwerp Polyglot Bible, Ladino Pentateuch, Ferrara Bible, Juan de Valdés, Francisco de Enzinas, Juan Pérez de Pineda, Casiodoro de Reina, Bear Bible, Cipriano de Valera, Pitcher Bible, ReinaValera Bible, religious persecution, censorship, Jewish diaspora, Protestant diaspora. 


\section{ANTECEDENTES}

Los testimonios más antiguos de la presencia de traducciones bíblicas en la península ibérica se remontan a mediados del siglo III y permiten inferir el uso entre la población cristianizada de la Vetus latina, traducción de la Septuaginta griega ${ }^{1}$. La primera mención explícita a una traducción concreta de la Biblia cristiana es la carta fechada en 398 y enviada por dos ricos cristianos (Lucinio Bético y su esposa Teodora) a Jerónimo de Estridón junto con seis amanuenses solicitando copias de algunos libros de lo que más tarde sería la Vulgata, que Jerónimo tradujo entre 390 y 404. No hay consenso sobre la existencia de una Vetus latina hecha en suelo hispano. Las primeras traducciones bíblicas en lengua vernácula de las que hay constancia que se realizaran en la península se hicieron al árabe en el siglo Ix (López Guix, 2013). Las siguientes de las que disponemos testimonios son las llamadas biblias medievales romanceadas, conservadas en manuscritos fechados entre los siglos XIII y XV. Entre los manuscritos más antiguos se encuentran $L a$ fazienda de ultramar, una guía de peregrinos en Tierra Santa con fragmentos de los libros históricos y proféticos y un Salterio bilingüe prealfonsí, ambos de finales del siglo XII o principios del

I La primera referencia se encuentra en una carta de Cipriano de Cartago, santo de origen bereber (como Agustín de Hipona), fechada en 254. Se trata de la respuesta a una petición de consejo en un conflicto en el seno de dos obispados peninsulares (el de León y Mérida y el de Astorga) y cita abundantemente textos bíblicos, cuyo conocimiento presupone en los destinatarios. No se menciona ninguna Biblia en concreto, pero las citas pertenecen a una Vetus latina de origen africano (Sánchez Caro, 2002: 338-339). En realidad, la denominación Vetus latina no hace referencia a una traducción concreta, sino al conjunto de versiones latinas del texto griego de la Septuaginta que circularon por el Mediterráneo en los primeros siglos del cristianismo. Fue la traducción defendida por Agustín de Hipona frente a la novedad que suponía la versión de Jerónimo. siglo XIII. De mediados de ese siglo es el Salterio de Hermann el Alemán (ca. 1200-1272), el primer traductor bíblico al castellano cuyo nombre conocemos $^{2}$, una versión que pudo realizarse en Toledo e inscribirse en el vasto proyecto político-cultural de Alfonso X (Sánchez-Prieto, 2002: 214). De los catorce manuscritos que nos han llegado, al menos diez están vinculados con la tradición o con traductores judíos (Lazar, 1994: 353). Dependen de la tradición de la Vulgata E2, E6 y E8, así como los manuscritos de la General estoria (Avenoza, 2008). Tres manuscritos poseen un texto bíblico completo, los manuscritos escurialenses E3 y E4 y la Biblia de Alba, de la primera mitad del siglo $\mathrm{XV}^{3}$. La abundancia de manuscritos relacionados con la tradición judía es lo esperable debido a que dentro del judaísmo la lectura de las escrituras sagradas era una obligación. El aprendizaje de la Torá comportaba una práctica traductora: Jonah ben Abraham Gerondi (ca. 1200-1264) recomienda para aprender la Torá leer dos veces el texto en hebreo y una en arameo y recurrir a una versión en vernáculo en caso de ausencia del arameo (Fernández López, 2003: 94). De todos modos, no nos han llegado manuscritos con semejantes traducciones. Quizá se tratara de una práctica oral; aunque también podría ser que se incluyeran en los textos bíblicos o litúrgicos traducciones interlineales o glosas en romance, siempre con una función vicaria y que se reelaborarían con el tiempo (Pérez Alonso, 2011: 396). En el siglo XVI, esa tradición se plasmaría en los textos impresos por los sefardíes en Salónica, Constantinopla y Ferrara.

\footnotetext{
2 No es nada seguro que Hermann tradujera del «hebraico», como se afirma al comienzo del texto, ni que supiera el suficiente romance para realizar la tarea (véanse Littlefield, 1983; Lapesa, 1981).

3 La página web del proyecto Biblia Medieval dirigido por Andrés Enrique-Arias alberga el corpus Biblias Hispánicas y constituye una valiosa plataforma digital de acceso libre: http://bh.bibliamedieval.es.
} 
Entre los cristianos, en cambio, no era en modo alguno obligatorio leer la Biblia. Los fragmentos bíblicos solían llegar al pueblo por intermediación de los clérigos, integrados en la liturgia, o vinculados al ejercicio de la piedad (salmos, pasajes neotestamentarios, fragmentos incluidos en libros de horas) (Avenoza, 2008: 14). En cualquier caso, la lectura de la Biblia en vulgar no debía de ser una práctica rara a comienzos del siglo XIII, pues en 1233, bajo Jaime I de Aragón, el Concilio de Tarragona, promulgó la que se considera la primera prohibición hispana de textos religiosos en vulgar (es posible que fueran en occitano o provenzal) y hubo otra un siglo después, en 1317, orientadas ambas a combatir las herejías de beguinos, valdenses o albigenses (Fernández López, 2003: 89-96). Estas prohibiciones estuvieron circunscritas al ámbito de la Corona de Aragón, aunque hay un Salterio catalán de finales del XIII o principios del XIV realizado por Romeu Sabruguera. Circularon sin trabas traducciones parciales, como los Evangelios e epístolas de todo el anyo con sus exposiciones en romance de Gonzalo García de Santa María (Zaragoza, 1485; Salamanca, 1493), traducción de un texto latino (1437) del obispo de París Guillermo de Auvernia, la primera impresión de un texto bíblico en castellano.

En el siglo XV, tras los pogromos generalizados de 1391, hubo bajo los reinados de Alfonso V de Aragón llamado el Magnánimo (1396-1458) y Juan II de Castilla (1398-1476), tío y padre respectivamente de los futuros Reyes Católicos, una mejora de la situación de los judíos y un clima favorable del que nacieron los romanceamientos medievales que nos han llegado, hechos a partir del hebreo (Pérez Alonso, 2011: 399). Muestra paradigmática del interés en los ambientes cortesanos y cultos por un texto bíblico traducido es la mencionada Biblia de Alba (1422-1431), encargada por Luis de Guzmán, gran maestre de la Orden de Calatrava, a Moshé Arragel de Guadalajara o la llamada Biblia del Marqués de Santillana, conservada en los manuscritos BNE MSS/10288 y BNE MSS/9556 (a los que habría que sumar un primer volumen con partes contenidas en E4), encargada por Íñigo López de Menoza al converso Martín de Lucena (Enrique-Arias y Pueyo, 2017). La situación cambiaría de nuevo tras la unión política de los Reyes Católicos, cuando se emprendió también la unión religiosa. A partir de finales del siglo Xv, hay noticias de quemas de Biblias en Toledo en 1490 y en Salamanca en 1492 (Fernández López, 2003: 141-143).

En el curso del siglo XVI se vivió de modo especial la tensión relacionada con la traducción a la que se enfrenta toda escritura sagrada (¿hasta qué punto es traducible una palabra divina?) y, sobre todo, con el poder de la traducción como instrumento para desestabilizar jerarquías establecidas. Durante ese siglo, la Iglesia católica intentó contener el impulso hacia la traducción que mostraron sectores cristianos llevados por el afán de renovación y vuelta a las fuentes que fue característico del humanismo. Se vivió entonces en toda su aspereza el choque entre tradición y traducción; en el ámbito hispánico, la ortodoxia católica acabó alzando un poderoso muro en torno a la autoridad de la Vulgata, mientras que extramuros (y también intramuros) algunos sectores cristianos abrazaron (o intentaron abrazar en la medida de sus posibilidades) el impulso hacia la traducción que era, en realidad, consustancial al cristianismo desde sus inicios. Por su parte, el judaísmo de origen peninsular, fuera ya de la península y a salvo de las persecuciones de la monarquía hispánica y la Inquisición, también impulsó la impresión de traducciones de sus escrituras sagradas.

Resulta difícil sustraerse a la tentación de recordar la frase de Dickens «Era el mejor de los tiempos, era el peor de los tiempos...». La ortodoxia se impuso sobre todos los habitantes del reino pe- 
ninsular unificado. La última década del siglo $\mathrm{XV}$ había visto la expulsión de los judíos y la quema en 1498 de la Biblia valenciana impresa veinte años antes, una Biblia en catalán que había sido la primera en imprimirse en la península ibérica y que fue también la primera impresa en ser quemada $^{4}$. La historiografía reciente ha puesto en duda el relato de varios miles de libros, entre ellos Coranes y valiosos manuscritos, quemados por orden del cardenal Cisneros nada más empezar el siglo en la plaza granadina de Bib-Rambla (Salvador, 2016); sin embargo, es innegable que los Reyes Católicos emitieron el 12 de octubre de 1501 una real cédula ordenando a las autoridades granadinas el requisado y la quema pública de libros («que ningun quede Alcorran ni de la seta mahometica» (Meneses, 1973: 299). El siglo continuó con censuras, prohibiciones y persecuciones de traductores y traducciones. Sin embargo, también produjo grandes traducciones, dos de ellas patrocinadas por las más altas figuras del poder religioso y político establecido, el cardenal Cisneros y el monarca Felipe II. Este artículo repasa dichas iniciativas oficiales, que incluyeron el texto bíblico en diversos idiomas, y a continuación esboza someramente la situación de la traducción bíblica al castellano en el seno del cristianismo y el judaísmo de origen hispano en el siglo xvI.

\section{LA ORTODOXIA CATÓLICA Y SUS LÍMITES}

A mediados de la segunda década se imprimió en Alcalá de Henares, auspiciada y financiada por el

4 Contenía traducción del latín al valenciano que habían realizado entre 1396 y 1402 Bonifacio Ferrer y otros monjes de la Cartuja de Porta Coeli (Valencia) y que revisó para su impresión Jaume Borrell, inquisidor del reino de Valencia. Fue la cuarta en lengua vernácula en imprimirse, tras la alemana, la italiana y la neerlandesa. Un incendio en la Biblioteca Real de Estocolmo destruyó en 1697 el último ejemplar conocido de la tirada original de 600 . Sobrevive la última página, en poder de la Hispanic Society, en Nueva York. cardenal Cisneros, la Biblia políglota complutense, una obra que recibió elogios mayúsculos por parte de Marcelino Menéndez Pelayo y de Marcel Bataillon. El primero dijo que era un «monumento de eterna gloria para España» y «en su línea, el mayor esfuerzo que desde las Hexaplas de Orígenes se había intentado en el mundo cristiano» (1916: 32, 33); y el segundo la consideró como «la gloria de Alcalá en los anales del humanismo, una de las obras más imponentes que llevó a cabo en esta época la ciencia de los filólogos auxiliada por el arte del impresor» (1966: 22). Mediado el siglo apareció en Amberes una segunda políglota, auspiciada por Felipe II y dirigida por Benito Arias Montano. Fueron las dos primeras Biblias políglotas en imprimirse y de ellas se ha dicho que su publicación llevó al «Renacimiento español a la vanguardia del Humanismo» (Fernández Marcos 2012: 334). A pesar de estar amparada por las mayores instancias del poder de la época, la génesis de esas dos obras revela las tensiones relacionadas con la traducción y el control de las interpretaciones. Ninguna de ellas incluía una lengua vernácula contemporánea. Las traducciones realizadas fuera de ese patrocinio oficial experimentaron dificultades aun mayores y muchas veces insuperables.

\section{La Biblia políglota complutense}

En el ámbito de la traducción bíblica, el siglo xvI se inició en los territorios de la monarquía hispánica con la edición sufragada y dirigida por el cardenal Francisco Jiménez de Cisneros (14361517) de la Biblia políglota complutense, impresa entre 1514 y 1517 en Alcalá de Henares, por Arnao Guillén de Brocar (ca.1460-1523).

Cisneros quiso contar con la colaboración de los mayores especialistas en lenguas clásicas y orientales del momento y llegó a invitar a Erasmo de Rotterdam. Sin embargo, éste declinó la oferta, y es célebre el «Non placet Hispania» que 


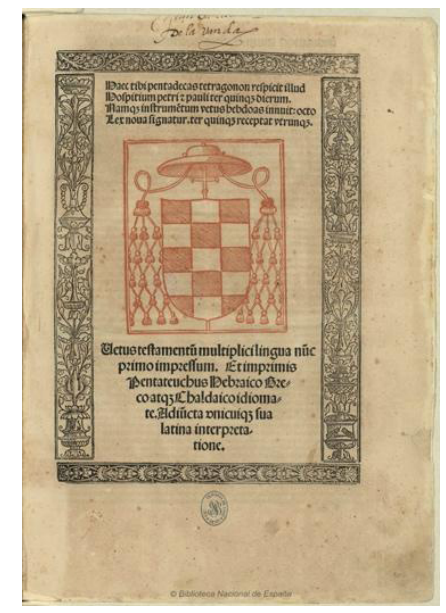

IMAGEN I. Portada del primer volumen de la Biblia políglota complutense (1517)

escribió a Tomás Moro a propósito, entre otros motivos (no tenía gran aprecio por el Antiguo Testamento), de su renuencia a vivir en una tierra que consideraba excesivamente judaizada (Bataillon, 1966: 77-78). Tampoco se repararon esfuerzos para obtener los mejores manuscritos ni para conseguir la mayor calidad en la impresión de la obra. La tarea se llevó a cabo en la Universidad de Alcalá de Henares, fundada (14981508) por el propio Cisneros con el objetivo de renovar la enseñanza teológica española.

La obra consta de seis volúmenes infolio con textos en hebreo, arameo, griego y latín. No se conoce con exactitud el nombre de todos los colaboradores. De la edición del hebreo y el arameo se encargaron principalmente Pablo Coronel, Alfonso de Zamora y Alfonso de Alcalá, todos ellos conversos $^{5}$. En la revisión del griego y el latín in-

\footnotetext{
5 Alfonso de Zamora también prepararía con ayuda de Pedro Ciruelo y fuera del proyecto complutense versiones interlineales latinas de diversos libros de la Biblia hebrea para uso docente en Alcalá y Salamanca; el manuscrito más antiguo que se conoce es de 1526 (Fernández López, 2009: 89).
}

tervinieron los helenistas, latinistas y especialistas en lenguas orientales Demetrio Ducas el Cretense (ca.1480-1527), Diego López de Zúñiga (ca. 1470-1531), Juan de Vergara (1492-1557), Hernán Núñez el Pinciano (ca.1478-1553) y Bartolomé de Castro (¿?-antes de 1522). Antonio de Nebrija (1444-1522) tuvo una participación fugaz en el proyecto: se incorporó a él como latinista para la revisión de la parte de la Vulgata, pero enseguida lo abandonó en desacuerdo con los criterios generales establecidos por Cisneros (Bataillon, 1966: 34-39) ${ }^{6}$.

La edición destaca por su voluntad didáctica. Así, en el Antiguo Testamento, las palabras del texto hebreo y la traducción de Jerónimo están marcadas con pares de letras en voladita que relacionan las palabras de uno y otro idioma, esas letras voladas son usadas en el margen para señalar las raíces hebreas consultables en el volumen del diccionario, el griego de la Septuaginta va acompañado de una traducción interlineal en latín, los márgenes también se utilizan para añadir referencias a otros pasajes bíblicos (Carbajosa, 2014: 24-26). La tirada constó de dos emisiones: una de unos 600 ejemplares en papel y otra reducida (6) en pergamino (vitela). El precio de venta de la obra completa fue de 6,5 ducados de oro, una suma muy elevada en esa época.

El primer volumen en editarse fue el V, correspondiente al Nuevo Testamento, cuyo colofón ofrece la fecha del 10 de enero de 1514 . Compuesto a dos columnas, contiene el texto neotestamentario en griego (Septuaginta) y en latín (Vulgata).

Los tipos griegos utilizados en ese volumen se inspiraron en manuscritos de los siglos XI-XII (Fernández Marcos 1997: 220); y, en relación con

6 Nebrija fue el primero de los grandes humanistas del siglo en tener roces con la Inquisición: el gran inquisidor Diego de Deza le incautó en 1505 todos sus papeles, que solo le fueron devueltos gracias a la intervención de Cisneros (Gil, 1997: 407). 
22

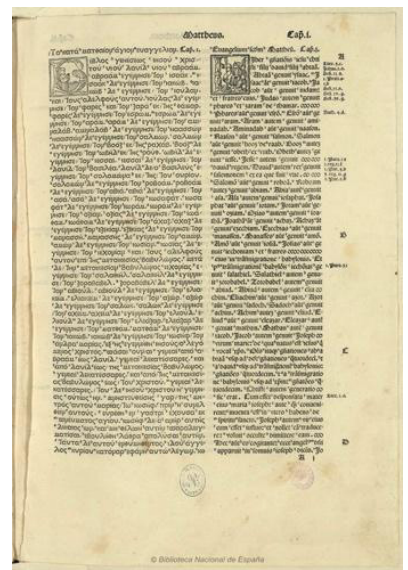

IMAGEN 2. Inicio del Evangelio de Mateo en la Biblia políglota complutense (1514), vol. V

ellos, es muy citada la frase de Robert Proctor (1900: 144), bibliógrafo y experto en incunables y tipografía: «To Spain belongs the honour of having produced as her first Greek type what is undoubtedly the finest Greek font ever cut» (A España le corresponde el honor de que los primeros moldes griegos que fabricó sean sin duda los tipos griegos más elegantes jamás fundidos).

El siguiente volumen en imprimirse, en la primavera de 1515, fue el VI, con un glosario hebreo y caldeo (arameo) del Antiguo Testamento, así como una gramática hebrea. A continuación, los volúmenes restantes, del I al IV, con el Antiguo Testamento, terminaron de imprimirse el 10 de julio de 1517, cuatro meses antes de la muerte del cardenal.

La cronología de la impresión del conjunto de la obra y la disposición en la página de los textos veterotestamentarios, incluso algunas elecciones tipográficas (como la diferencia de tipos para el griego del Nuevo y el Antiguo Testamento), señalan claramente la primacía de la perspectiva cristiana y reafirman el poder fundado sobre la Vulgata y su interpretación. En los cuatro volúmenes del Anti-

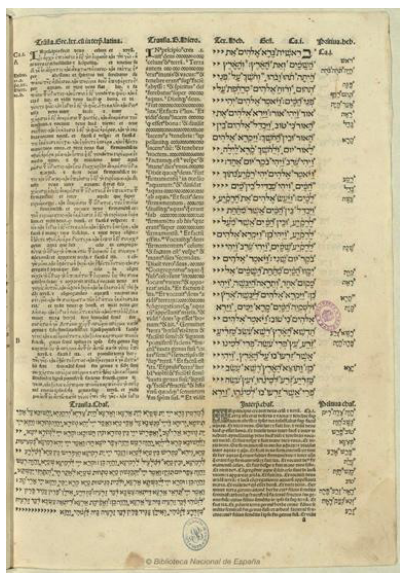

IMAGEN 3. Inicio del Génesis en la Biblia políglota complutense (1517), vol. I

guo Testamento, los textos bíblicos están dispuestos en tres columnas, con el latín en el centro, el hebreo junto al margen exterior y el griego junto al interior; en la parte del Pentateuco, la sección inferior de la página se divide en dos columnas con el Targum de Onquelos (la traducción aramea de la Torá) y su traducción latina.

En el prólogo al lector, Cisneros escribe a propósito de esa disposición de los textos de las tres lenguas principales: «En medio hemos colocado la traducción latina del bienaventurado Jerónimo entre la Sinagoga y la Iglesia oriental, que son como los dos ladrones, uno a cada lado, y Jesús, esto es la Iglesia romana o latina, en medio». Se ha interpretado a veces esta centralidad como una aserción de autoridad textual de la traducción jeronimiana sobre los originales hebreos, pero, como ya señaló a mediados del siglo xIX el teólogo católico alemán Karl Joseph von Hefele, lo que se afirma en realidad es la superioridad de las Iglesias, no de los textos (Hefele, 1869: 90). La distinción es relevante, pero resulta difícil sustraerse a la equiparación entre las Iglesias y los textos sobre los que basan su autoridad, por 
más que se afirme que el hebreo es el original y teniendo en cuenta además la tradición medieval de la superioridad del latín sobre las otras lenguas en los pasajes dudosos de las Escrituras. De hecho, el abandono del proyecto por parte de Nebrija se explica por desacuerdos en torno a la sacralidad de lo fijado por la tradición: «Vuestra Señoría me dixo que hiziese aquello mesmo que a los otros havía mandado, que no se hiziese mudança alguna de lo que común mente se halla en los libros antiguos», escribió Nebrija al cardenal (Jiménez, 2016: 254 y ss.).

La empresa de la Políglota no tuvo un final feliz. La impresión de la obra concluyó a mediados de 1517, pero el cardenal murió en noviembre de ese mismo año, antes de haber obtenido la aprobación papal (que no se logró hasta 1520). Muy posiblemente los ejemplares no circularon hasta 1522 (Martín, 2016: 322); y eso, los que circularon, puesto que una buena parte de la tirada se hundió rumbo a Roma, donde el papa debía visar los ejemplares (Fernández Marcos, 2016: 235). Para entonces, no solo Erasmo había publicado su Novum Instrumentum (1516), que llevaba ya tres ediciones y se convirtió (a pesar de ser textualmente inferior a la Políglota) en el textus receptus del Nuevo Testamento, y también Aldo Manucio había imprimido en Venecia su edición de la Septuaginta (1518) ${ }^{7}$.

La Políglota complutense, con su combinación única de las tradiciones exegéticas cristiana y judía, su yuxtaposición del texto latino de Jerónimo de Estridón y los textos bíblicos en hebreo y arameo, junto con su traducción latina, así como los materiales filológicos del último volumen pre-

\footnotetext{
Por su parte, Lutero y su círculo usarían para la traducción del Nuevo Testamento (1522) la segunda edición de Erasmo (1519) y, para el Antiguo Testamento (1534), la Biblia hebrea publicada en Italia por Yehoshúa Shlomó Soncino (1488), la primera en salir de una imprenta (Fernández Marcos, 2016: 235).
}

parados por los conversos, representantes de la tradición sefardí medieval, no tuvo la repercusión que habría merecido. Lo que podía haber sido una monumental contribución hispana al humanismo europeo fue, en realidad, un monumento que apenas tuvo ocasión de contar con admiradores entre sus contemporáneos. En la medida en que tuvo influencia la tuvo de modo vicario a través de la reimpresión fragmentaria de su contenido, a veces sin mención alguna de la procedencia, o de su utilización para preparar nuevas ediciones y traducciones (García Pinilla, 2016). Hoy sobreviven un centenar de ejemplares.

\section{Contexto cambiante y Trento}

Por otra parte, el clima intelectual empezó a cambiar rápidamente, tanto en la península ibérica como en Europa. Con la publicación de las llamadas «tesis» de Lutero a finales de $1517^{8}$, se inició en el seno del cristianismo una profunda división que desembocaría en terribles persecuciones y enfrentamientos. En la península, la década de 1520 vio la erradicación del movimiento de los alumbrados, unos heterodoxos considerados cercanos a las ideas de Lutero (quien en 1521 fue excomulgado por el papa León $\mathrm{X}$ y prohibido y declarado prófugo por el emperador Carlos V en la dieta de Worms). El inicio en 1525 del proceso contra Isabel de la

8 La publicación de la tesis coincidió en el tiempo con la muerte de Cisneros, ocurrida en la madrugada del 8 de noviembre de ese año. Según la leyenda, las 95 tesis sobre las indulgencias fueron clavadas en la puerta de la iglesia del castillo de Wittenberg el 31 de octubre de 1517. En realidad, fue Melanchthon quien mencionó por primera vez en $1546 \mathrm{el}$ supuesto episodio de los martillazos en la puerta de la iglesia ocurrido tres décadas antes. Al parecer, en esa fecha sí que envió Lutero una carta de protesta con sus tesis al arzobispo de Maguncia y Magdeburgo. Fueron 95 según la posterior numeración de los impresores; en el manuscrito no estaban numeradas (García-Villoslada, 2016: 334 y ss.). 
24 Cruz y Pedro Ruiz de Alcaraz, en «el primer enfrentamiento del emperador y la Inquisición moderna con la heterodoxia» (Cabanal, 2001: $310)$, culminó en su condena en 1529 y enlazó en 1530 con la quema en la hoguera inquisitorial de Juan López de Celaín, capellán de la Capilla Real de Granada, por «luterano y alumbrado» (Márquez, 1972: 69). Se inició así una segunda década de persecución y juicios contra erasmistas y protestantes, durante la cual se aprovechó la partida (1529) de Carlos V y la corte (con sus importantes protectores) a Bolonia para su coronación como emperador del Sacro Imperio Romano Germánico y luego a diversos lugares llevado por otras cuestiones imperiales europeas ${ }^{9}$. Como escribió Joseph Pérez (2014: 264), «la "invasión erasmiana”, a pesar de alta protección en la corte, suscitó pronto suspicacias entre los inquisidores, que no siempre distinguían -o no querían distinguir - entre erasmistas, alumbrados y luteranos». Y, en relación con el legado complutense, Pérez añadió: «a mediados del siglo XVI, ser complutense empieza, pues, a ser sospechoso; es casi indicio de, al menos, erasmismo, cuando no de luteranismo o de cualquier forma de heterodoxia».

Así, por ejemplo, en 1530 la Inquisición detuvo a Bernardino de Tovar, que había pertenecido al círculo alumbrado de Francisca Hernández, lo que se considera el inicio de la persecución de los erasmistas peninsulares. Y en 1533 fue detenido y encarcelado cuatro años, hasta 1537, su

9 Cabe recordar que el propio Carlos, favorable a la causa erasmiana, había promovido en 1527 la Conferencia de Valladolid para examinar la ortodoxia de la doctrina del pensador, suspendida sin condena oficial por el inquisidor general Alonso Manrique, él mismo erasmista (Bataillon, 1966: 236 y ss.). Como arzobispo de Sevilla, Manrique reformó la antigua mezquita de Córdoba para insertar en su centro una gran nave cristiana renacentista que desfiguró el edificio original. Fue también hermanastro del poeta Jorge Manrique y protector de Juan de Valdés. hermano, el helenista Juan de Vergara, secretario personal de Cisneros y colaborador de la Políglota complutense. Poco después, se inició el concilio de Trento (1545), que sentó las bases de la Contrarreforma y que se celebró en tres grandes bloques de sesiones: 1545-1547, 1551-1552, 15621563. El concilio declaró (1546) la Vulgata como versión «auténtica» (confirmando con ello la posición tradicional, sostenida por Cisneros, en relación con la autoridad del texto de Jerónimo). En esas primeras sesiones se discutió la pertinencia de la traducción de la Biblia, aunque no se estipuló entonces nada al respecto debido a la disparidad de prácticas en los diferentes países (en algunos, la traducción estaba prohibida, y en otros, no). Surgieron acerbas discusiones entre partidarios de permitirlas (encabezados por el cardenal de Trento, Cristoforo Madruzzo) y de prohibirlas (encabezados por el cardenal de Jaén, Pedro Pacheco, y Alfonso de Castro). Una postura intermedia fue defendida por Bartolomé Carranza ${ }^{10}$, futuro arzobispo de Toledo, quien intentó diferenciar en el contenido de la Biblia entre aspectos dogmáticos y devocionales y permitir la traducción de los libros que contenían los segundos: los históricos y sapienciales en el Antiguo Testamento y, en el Nuevo, algunos evangelios, algunas epístolas y los Hechos de los apóstoles (Fernández López, 2003: 211-232). Sin embargo, lo enconado de las posiciones no permitió llegar a ningún acuerdo y llevó a postergar la cuestión. En un período entre sesiones, con el concilio suspendido, el asunto se debatió en la Universidad de Lovaina, contexto en el que el valenciano Fadrique Furió Ceriol (1527-1592) redactó Bononia, sive de libris sacris in vernaculam

Io Nombrado arzobispo de Toledo en 1558, Bartolomé Carranza sería encarcelado en 1559 por la Inquisición acusado de herejía y su proceso, llevado en 1567 a Roma, se prolongaría hasta 1576 , pocos meses antes de su muerte. 
linguam convertendis (1556) ${ }^{11}$, según Bataillon (1966: 552), «la defensa más atrevida que una pluma española haya escrito jamás en favor de estas traducciones». Furió fue inmediatamente encarcelado por la Inquisición de Lovaina.

En realidad, el Concilio de Trento finalizó (1563) sin zanjar formalmente la cuestión. De todos modos, la regla cuarta del Índice que surgiría de Trento se decantaría sin ambages al año siguiente por la prohibición, aunque permitiendo un fino resquicio para conceder excepcionalmente licencias que sería aprovechado retóricamente algo después por Casiodoro de Reina.

De todos modos, en el ámbito de la monarquía hispánica, desde antes incluso de Trento, la lectura de la Biblia en vulgar fue objeto de estrecha supervisión. Las listas de libros prohibidos iniciadas en 1521 con la prohibición de las obras de Lutero se repitieron en 1540 y $1545^{12}$. Esas listas culminarían en la prohibición inquisitorial de toda

II El título de la obra se deriva del nombre del teólogo Juan de Bolonia, con quien Furió mantuvo ese debate en la universidad de Bolonia y a quien convirtió en interlocutor del diálogo reflejado en el libro. La obra se imprimió en Basilea, en la imprenta de Johannes Oporinus. Furió tuvo dificultades para encontrar un impresor. Como recuerda Fernández López (2003: 203), la coyuntura política europea se volvió en ese momento poco propicia: la dieta de Augsburgo abolió la tolerancia religiosa en los Estados alemanes, los Países Bajos recayeron en herencia a Felipe II (quien inició una catolización del territorio y alimentaría la revuelta que estallaría en la siguiente década) y en Roma ascendió al trono pontificio Pietro Caraffa con el nombre de Paulo IV. Furió también empezó a escribir un tratado de teoría política, cuya primera parte, El Concejo, $i$ consejeros del Príncipe (1559), obtuvo gran éxito, fue traducido inmediatamente a varios idiomas, pero le valió nuevos problemas. Volvió a España años más tarde tras llegar con los representantes del rey a un pacto mediante el cual se le perdonarían las culpas, se le pagarían sus deudas y se le garantizaría un modo de vida a cambio de no escribir el tratado político proyectado.

${ }^{12}$ Fernández López (2003: 115-116) menciona la concesión de una licencia para leer la Biblia en vulgar a la duquesa de Soma en 1543 y los temores de un librero de Amberes en 1549. traducción en lengua vulgar y el Índice de Fernando Valdés de 1551 (que incorporó el catálogo de Lovaina de 1550 con añadidos hispanos), la Censura General de Biblias de 1554 (en la que intervino Bartolomé Carranza), un nuevo Índice valdesiano en 1559 o el Índice de Quiroga de $1583^{13}$.

\section{La Biblia políglota de Amberes o Biblia regia}

Concebida como una reedición medio siglo después de la Biblia políglota complutense, la segunda Biblia políglota, la Biblia regia publicada en Amberes en 1569-1572, ofrece un nuevo ejemplo ilustrativo de las tensiones dentro de la ortodoxia romana en relación con la publicación de las Sagradas Escrituras y su traducción.

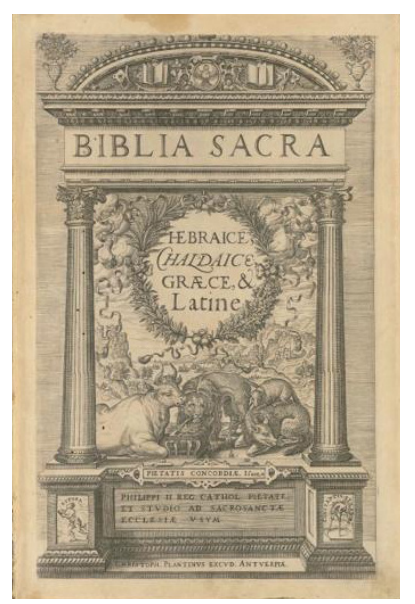

IMAGEN 4. Portada del primer volumen de la Biblia Políglota de Amberes (1569-1572)

13 Charles Lea y Marcel Bataillon señalaron la existencia de un Índice español de libros prohibidos fechado en 1547, un dato repetido luego por otros investigadores. Sin embargo, Jesús M. de Bujanda (1984) ha mostrado que la carta en el que se basa dicha afirmación contiene un error de copista y debe leerse 1551 en lugar de 1547. 
Al parecer, la iniciativa partió del impresor Cristóbal Plantino (ca.1520-1589), radicado en Amberes, quien llevaba unos años intentando conseguir patrocinadores para su proyecto de imprimir una Biblia políglota ${ }^{14}$. Plantino había presentado con anterioridad el proyecto a otros posibles patrocinadores europeos y, tras la revuelta calvinista que estalló en Amberes a mediados de 1566, juzgó prudente (ya había sido acusado de herejía en 1561-1562) buscar el patrocinio del rey católico a través de Gabriel de Zayas, secretario de Felipe II y conocido suyo de Amberes (Macías, 1998: 6570). El rey pidió informes a diversas instancias ${ }^{15} y$, tras aprobar la propuesta, encargó a Benito Arias Montano (1527-1598) que supervisara personalmente la edición de la obra (Macías, 1998: XXI y ss.). Arias Montano llegó en 1568 a Flandes, con una carta del rey al duque de Alba, su máxima autoridad en el territorio, donde se le pedía que se le dieran todas las facilidades para cumplir la tarea encomendada, concebida como una reedición de la Biblia de Cisneros, y se hacía mención a su importancia y necesidad: la Biblia impresa medio siglo antes en Alcalá, «una de las obras más insignes y más útiles á la Iglesia universal» era ya inencontrable porque «por haberse perdido en la mar una gran multitud dellas llevándolas á Italia, han quedado tan pocas que ya no se hallan sino en poder de personas particulares y á muy subido precio» (González Carvajal, 1832: 144).

Arias Montano enseguida congenió con el grupo de eruditos reunidos para el proyecto por

${ }^{14}$ Se ha dicho (Max Lossen en 1886, citado por Domínguez, 2015: 140) que tras Plantino pudo estar como inspirador el gran orientalista francés Guillermo Postel, un personaje excéntrico a quien la Inquisición acabaría dando por loco: non malus sed amens.

${ }^{15}$ Al parecer, consultó al hebraísta salmantino Martín Martínez Cantalapiedra, a Juan de Regla, delegado en el Concilio de Trento y antiguo confesor de Carlos V, a su capellán Benito Arias Montano, así como al Consejo General de la Inquisición y la Facultad de Teología de Alcalá de Henares.
Plantino y con aquellos que lo visitaban regularmente. Los colaboradores constituían un variado grupo de teólogos y humanistas entre los que había protestantes, católicos y cabalistas cristianos (Wilkinson, 2007). Bajo la protección de Felipe II, la Políglota de Amberes consiguió aunar la tradición humanística hispana (con su herencia judía medieval) representada por Arias Montano y los esfuerzos del grupo de eruditos del norte de Europa congregado por Plantino, unidos todos ellos a pesar de sus diferencias doctrinales por el deseo de obtener un texto sagrado depurado por medio de un método filológico riguroso (Portuondo, 2019: 97).

La obra está formada por ocho volúmenes. Los cinco primeros contienen los textos bíblicos, como en el caso de la Biblia complutense, pero en cinco lenguas, puesto que se añade el siríaco. Los cuatro primeros volúmenes del Antiguo Testamento ofrecen el texto hebreo, aprovechando la Complutense pero usando como base principalmente la Biblia rabínica (1524-1525) con el texto masorético preparada por el sefardí tunecino Jacob ben Hayim y editada por Daniel Bomberg $^{16}$, el texto latino de la Vulgata, la versión griega de la Septuaginta y su traducción al latín, así como el Targum (paráfrasis aramea) de todo el Antiguo Testamento junto con su traducción al latín (un material preparado por Alfonso de Zamora para la Políglota complutense, donde solo usó la parte del Pentateuco, con el latín revisado por Arias Montano).

\footnotetext{
I6 Se siguió el texto masorético, pero organizando los capítulos y numerando los versículos según la Vulgata. Como dice Theodor Dunkelgrün (2012: 320), el resultado fue «un cuidadoso camino intermedio entre la Biblia complutense y la Biblia hebrea de Bomberg, entre la tradición cristiana y la transmisión judía. [...] La lectio era judía, el ordo cristiano». La llamada Segunda Biblia rabínica fue usada también por Casiodoro de Reina y, casi un siglo después, por los traductores la Biblia del rey Jacobo.
} 

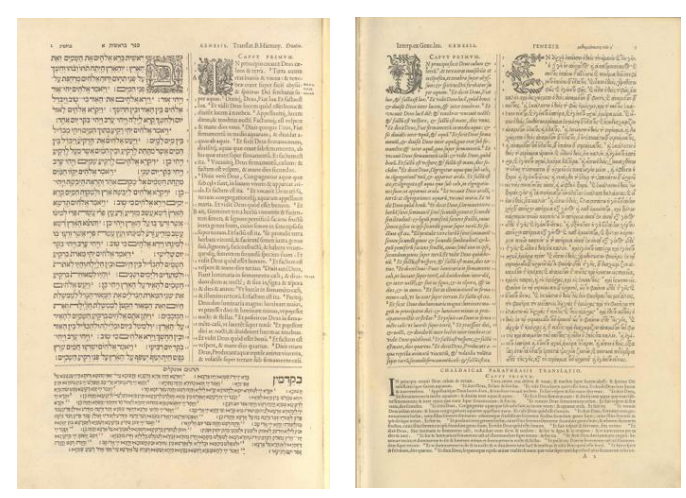

IMÁGENES 5 Y 6. Principio del Génesis en la Biblia políglota de Amberes (1569), vol. I

A diferencia de la Complutense, los textos se disponen en dos páginas enfrentadas y no en una sola. Las páginas están divididas en dos columnas verticales y el quinto inferior sin dividir. El latín ocupa la posición interior, de modo que se presenta en una posición de centralidad. En el Antiguo Testamento, el hebreo y el griego están en la columna exterior, con el Targum en la parte inferior en la página par y su traducción latina en la impar.

El quinto volumen, con el Nuevo Testamento, contiene el texto griego, la Vulgata y la versión siríaca contenida en la Peshitta ${ }^{17}$ junto con su traducción latina (realizada por el orientalista francés Guy Le Fèvre de la Boderie, discípulo de Guillermo Postel) y también su transliteración en caracteres hebreos. La página par contiene las dos columnas de la Peshitta en siríaco y su tra-

${ }^{17}$ La Peshitta contiene una versión al siríaco (arameo tardío) de la Biblia hebrea y del Nuevo Testamento, sin el Apocalipsis y las cuatro epístolas católicas menores: 1 Pedro, 2 y 3 Juan y Judas. (Se llaman epístolas católicas o generales las siete que no tienen ningún destinatario concreto, a diferencia de las paulinas, que sí lo tienen y tras las cuales van situadas en el Nuevo Testamento.) La Peshitta se convirtió a partir de principios del siglo $\mathrm{v}$ en el texto oficial de la Biblia entre los cristianos de habla siríaca. Al parecer, la parte del Antiguo Testamento había sido traducida un tiempo antes por judíos. ducción latina, y la página impar, la Septuaginta y la traducción latina de la Vulgata; abajo, en ambas, se presenta la transliteración del siríaco con caracteres hebreos.
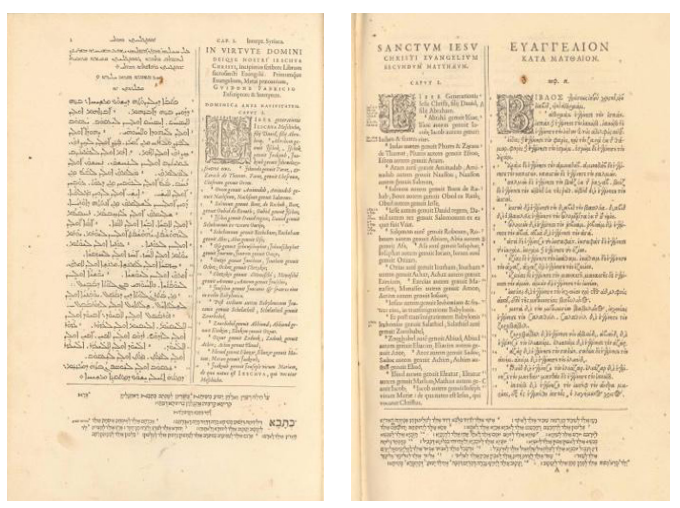

IMÁGENES 7 Y 8. Principio del Evangelio de Mateo en la Biblia políglota de Amberes (1571), vol. V

Los tres volúmenes restantes, publicados entre 1571 y 1572, contienen el llamado Aparato. El volumen vI, contiene gramáticas y léxicos hebreos, arameos, siríacos y griegos. El volumen VII un Nuevo Testamento en griego y una traducción interlineal latina realizada por Arias Montano revisando la Vulgata (con la versión de Jerónimo en el margen en los casos de divergencia); $y$, empezando por el final del volumen, en orden inverso de lectura según el uso occidental, una Biblia hebrea con la traducción interlineal latina de Santes Pagnino (una versión literalista publicada en 1527, revisada y ampliada luego por Miguel Servet) ${ }^{18}$. Y el volumen VIII, una especie de suma de estudios hebraicos, dibujos, mapas y tratados redactados (en su mayoría) por Arias Montano sobre geografía bíblica, realia, comentarios filológicos y bíblicos.

${ }^{18}$ Fue Santes Pagnino el primero en introducir en su versión la numeración de los versículos, si bien existía una división tradicional entre los soferim, precursores de los masoretas. 
Arias Montano revisó, por mandato expreso de Felipe II, todas las pruebas de imprenta ${ }^{19}$. Se tiraron 1.200 ejemplares de la Biblia, 13 en pergamino y 600 del Aparato $^{20}$.
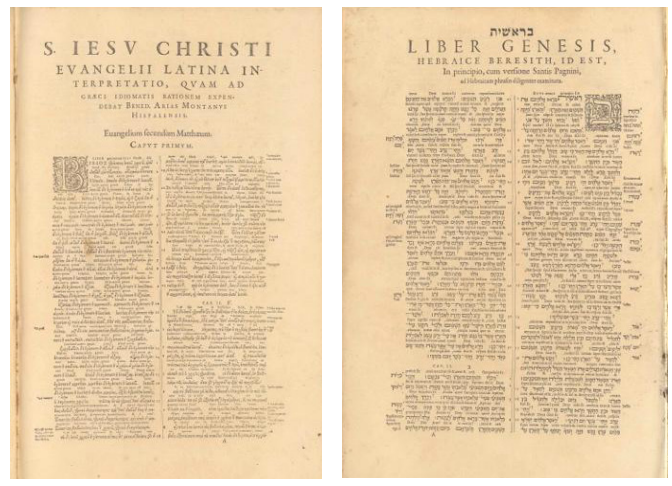

IMÁGENES 9 Y IO. Inicio del Evangelio de Mateo con la traducción de Arias Montano y del Génesis con la traducción de Santes

Pagnino en la Biblia políglota de Amberes (1572), vol. VII

A pesar de contar con el patrocinio regio, la atmósfera antirreformista dificultó sobremanera la tarea. La intención inicial de Arias Montano había sido utilizar en vez de la Vulgata la traducción más literal realizada por el dominico Santes Pagnino; sin embargo, la idea no recibió la apro-

I9 En la tarea de la corrección de las galeradas lo ayudó Madelaine, de trece años, la cuarta de las cinco hijas de Plantino, quien llevaba las galeradas a la casa de Arias Montano y leía en voz alta los textos hebreos, arameos, siríacos, griegos y latinos de las pruebas mientras el humanista cotejaba los originales (Sáenz-Badillos, 1997: 350). A partir de los cuatro o cinco años Plantino enseñó a leer a sus cinco hijas esas lenguas solo a leerlas, no las comprendían), para que hasta los doce o trece años echaran una mano en las tareas de corrección. En el margen de una galerada, una nota de Arias Montano al corrector redactada de modo excepcional en hebreo (para que Plantino no la entendiera en caso de verla) reza: «Debería decirle a esta niña que se apure a venir. Pues todos los días se demora demasiado» (Grafton, 2020: 95 y ss., cita en p. 98).

${ }^{20}$ Un censo de los ejemplares existentes conocidos se encuentra en el apéndice 1 de la tesis doctoral de Theodor Dunkelgrün (2012: 470-517). bación del claustro de la Facultad de Teología de Alcalá de Henares, y la cédula real indicó específicamente que la Vulgata debía ocupar el mismo lugar que en la Complutense dada su autoridad en la Iglesia: «pues siendo la más importante de todas la traducciones, no sería justo que faltara en una obra tan insigne o que se dejara de colocar en el lugar más destacado» (Macías, 2013: 17).

El teólogo escolástico León de Castro, catedrático de Retórica, Gramática Latina y Griego de la Universidad de Salamanca, feroz antagonista también de fray Luis de León y otros humanistas, luchó con todas sus fuerzas contra la obra de Arias Montano, incluso antes de su publicación. El propio Pío $\mathrm{V}$ rechazó conceder la aprobación papal a la obra y el privilegio para su impresión a Plantino. Las críticas se centraron fundamentalmente en la traducción veterotestamentaria de Santes Pagnino (cuya aparición había sido admitida como escolio) y en los tratados del último tomo. El método exegético de Arias Montano, aprendido de su maestro Cipriano de la Huerga (quien a su vez había estudiado con Alfonso de Zamora, profesor de hebreo en Salamanca y luego en Alcalá, así como hebraísta de la Biblia de Cisneros), suponía identificar mediante procedimientos numerológicos y cabalísticos los sentidos ocultos del hebreo ${ }^{21}$.

No constituye, pues, ninguna sorpresa que el peso acordado al hebreo, la presencia de la versión literalista de Santes Pagnino y la exégesis de los tratados montanianos (en especial, De arcano sermone) hicieran que los más apegados a la ortodoxia tacharan toda la obra de cabalística y judaizante y consideraran (con razón) que

${ }^{21}$ No cabe olvidar que el hebreo se consideraba la lengua primigenia en la que Dios había hablado y con la que Adán había dado nombre a las cosas. La idea fue sostenida por los Padres de la Iglesia y durante toda la Edad Media y defendida con vehemencia por el «erudito utopista» Postel (Eco, 1994: 73-76). 
socavaba la posición de la Vulgata cuya consideración como legítima o como traducción autorizada por el Concilio de Trento la envolvía a sus ojos de canonicidad y la hacía superior incluso al original hebreo (Macías, 2013: 31) ${ }^{22}$.

A esas diferencias doctrinales se superpuso otra cuestión de índole material y también política: el monopolio sobre la venta de libros litúrgicos. Al finalizar el Concilio de Trento (1563) quedó pendiente la uniformización de la enseñanza religiosa y los rezos canónicos (es decir, de catecismos, misales, breviarios, horas, etcétera) con objeto de lograr una unificación de cultos y ritos (cada diócesis, cada orden, tenía oraciones y configuraciones distintas). El concilio ya había dispuesto en 1546, en el mismo decreto en el que dictaminó que se tuviera por «auténtica... esta misma edición Vulgata, aprobada en la Iglesia por el largo uso de tantos siglos», que se imprimiera «con la mayor enmienda que sea posible la sagrada Escritura», es decir, realizar una edición crítica de la Vulgata (Sesión IV, Decreto sobre la edición y uso de la sagrada Escritura (López de Ayala, 1787: 37-38)). Felipe II contaba con utilizar el texto de la Vulgata de su Biblia regia como base para los libros del «nuevo rezado», otro gran proyecto editorial del rey y del que parcialmente también se encargó Arias Montano en la imprenta de Plantino. Sin embargo, ese proyecto encontró oposición por parte del papado y las administraciones eclesiásticas, con intereses también en el control de la venta de libros litúrgicos.

En juego estaban asimismo los intereses de importantes impresores y libreros deseosos de lograr privilegios reales o eclesiásticos que les

${ }^{22}$ En realidad, la propia idea de una políglota o de una simple yuxtaposición de versiones (por más que ninguna en vulgar) socavaba la autoridad de un texto considerado sagrado, un texto «santificado por un milenio de uso eclesiástico» y sobre el que «se fundamentaba la filosofía, la teología e incluso el derecho y la política» de la sociedad cristiana (Fernández Marcos, 2012: 251). permitirían publicar y comercializar los libros del nuevo rezado (como, por ejemplo, en los dominios hispanos, la imprenta plantiniana y los Junta, cuya rivalidad se prolongaría a lo largo del siglo siguiente (Moll, 1990)). De modo que los ataques a la Biblia de Montano y Plantino fueron una forma indirecta y segura de oposición a las pretensiones de Felipe II de lograr el monopolio en el negocio de los libros litúrgicos. Así, desde medios eclesiásticos, se difundieron rumores y falsas acusaciones sobre alteraciones introducidas en el texto bíblico. En esa atmósfera pudieron prosperar las denuncias de teólogos como León de Castro (o Guillermo Lindano en los Países Bajos), para quienes cualquier desviación del texto de la Vulgata era sinónimo de luteranismo y sesgo judaizante. León de Castro denunció, en 1574, la obra a la Inquisición. En 1575, Arias Montano (que no había logrado la aprobación de Pío $\mathrm{V}$ en 1572) acudió por segunda vez a Roma en busca del consentimiento pontificio; a pesar de los reparos por la presencia de la traducción de Santes Pagnino y los tratados del volumen VIII, Gregorio XIII acabó concediéndolo por deferencia en gran medida al monarca español y condicionándolo al beneplácito de la Inquisición española, que no emitió un dictamen favorable hasta $1577^{23}$.

No deja de resultar paradójico que la obra que iba a «ser para tanto servicio de nuestro Señor y bien de la Religión é Iglesia Católica», según los términos de la carta de Felipe II entregada por Arias Montano al duque de Alba en 1568 (González Carvajal, 1832: 144), se viera enredada en una mundana e inconfesada pugna de intereses

${ }^{23}$ Los ataques se reanudaron en 1579 , por parte del poderoso grupo dirigido por Pedro Vaca de Castro y Quiñones, arzobispo de Granada, que tenía interés en presionar a Arias Montano para que certificara la autenticidad de los libros plúmbeos hallados en el Sacromonte, una falsificación que no fue descartada por la Santa Sede hasta un siglo después (aunque las reliquias halladas junto a los libros se consideran auténticas) (Morocho, 1987: 136-139). 
políticos y económicos dentro del propio bando católico. Y no solo eso, sino que, en realidad, fue llevada a cabo por un grupo de eruditos entre los que no escasearon figuras de dudosa ortodoxia, cuando no considerados herejes, dirigidos por un humanista que, aun manteniéndose dentro de los límites de la ortodoxia católica, tuvo grandes problemas con ella y al cual posiblemente solo la protección del rey salvó de males mayores. Según Menéndez Pelayo (1992: 420), Felipe II lo honró «como quizá ningún monarca ha acertado a honrar a un sabio». Tras su muerte, continuaron los ataques contra él, y sus obras acabaron por ser incluidas en el Índice expurgatorio romano de 1607.

Paradójico resultó también el éxito de la Biblia regia. La utilizaron las dos grandes Políglotas del siglo XVII: la Políglota de París (1628-1655) reprodujo (con muchos errores en el hebreo) sus cinco primeros volúmenes, es decir, la Biblia en sí, deudora en realidad de la Complutense (cambiando por otro el texto siríaco en caracteres hebreos del Nuevo Testamento); y la Políglota de Londres (1654-1657), que fue dirigida por Brian Walton (futuro obispo anglicano) y que acabaría incluida en el Índice, reprodujo en el Antiguo Testamento la versión interlineal de Santes Pagnino corregida por Arias Montano y, en el Nuevo, su versión interlineal latina (Pérez Castro, 1970: 523-526).

Los recelos expresados tanto en Roma como en la propia península, así como el hecho de que la Inquisición incluyera las obras de Arias Montano en sus Índices, contribuyeron de modo notable a su prestigio en los lugares donde arraigó el luteranismo y el calvinismo. En ellos, la obra fue objeto de múltiples reediciones parciales; especial éxito concitó la parte del Aparato, en especial, sus dos últimos volúmenes, el vII y vIII de la Biblia regia, juzgados muy adecuados para el aprendizaje del hebreo y el griego bíblicos. El primero de ellos, con la versión de Santes Pagnino del Antiguo Testamento y, en el Nuevo, la ver- sión interlineal de Arias Montano; el segundo, con sus tratados de exégesis bíblica (Morocho, 1987: 166-167; Macías 2013: 40-42). En España, la obra de Montano y los humanistas del siglo XVI sería reivindicada dos siglos después por los ilustrados, como Benito Jerónimo Feijoo, Gregorio Mayáns o Gaspar Melchor de Jovellanos, quienes buscaron en ellos unos precursores en los que apoyar su pensamiento reformista (Morocho, 1987: 172-181, 189-193).

\section{Las traducciones de fray Luis de León y otras versiones}

La plantilla traductofóbica con la que importantes sectores eclesiásticos leyeron los decretos tridentinos en relación con las Escrituras y la posición de la Vulgata reflejaba la percepción cierta de que la apertura a la traducción suponía una apertura a la interpretación y, por lo tanto, una vía a la desestabilización de las jerarquías establecidas. Ello envolvió de sospecha toda traducción que no fuera la realizada más de mil años antes por Jerónimo de Estridón. Incluso las versiones latinas se consideraron con recelo cuando no con hostilidad; fue el caso de la mencionada traducción interlineal de Santes Pagnino, de la versión del benedictino italiano Isidoro Clario (1541-1542), defensor en Trento de la posición privilegiada de la Vulgata, y que acabó por ser incluida en el Índice de 1559, o de la llamada Biblia de Vatablo de 1545 (una versión de Santes Pagnino preparada por el impresor Robert Estienne con notas atribuidas a François Vatable), imprimida en Salamanca en 1555, prohibida en el Índice de Valdés y cuya ortodoxia fue discutida en 1569 por la Junta de Teólogos de la Universidad de Salamanca a petición del Consejo General de la Inquisición con motivo de la solicitud de una licencia para imprimir una segunda edición de la obra, en un momento de mayor tolerancia. 
Esa Biblia sería finalmente reeditada en 1584 y puesta a la venta en 1586. Sin embargo, en 1569 las discusiones de los teólogos salmantinos en torno a la conveniencia de su publicación y la introducción de correcciones se prolongaron durante dos años, y el enconamiento que resultó de esos debates dio lugar en 1571 a la denuncia ante el Santo Oficio con la que los dominicos León de Castro y Bartolomé de Medina y otros escolásticos conservadores consiguieron acallar (como no consiguieron hacerlo más tarde con Arias Montano) las voces abiertas a las nuevas tendencias interpretativas de fray Luis de León (ca. 1527-1591), catedrático de Teología, Gaspar de Grajar (1530-1575), catedrático de Biblia, y Martín Martínez Cantalapiedra (1518-1579), catedrático de Tres Lenguas. En marzo de 1572, los tres fueron detenidos y encarcelados en Valladolid, acusados, entre otras cosas, de usar una exégesis literal demasiado dependiente de las fuentes judías y que ponía en duda la posición de la Vulgata y la interpretación fijada por la Iglesia a partir de ella. Los tres, eminentes hebraístas, fueron conscientes de que detrás de las acusaciones existían rivalidades académicas e inquinas personales; ahora bien, más allá de ello, sus procesos no pueden dejar de verse «como el intento de acabar con estos modos de traducir, glosar e interpretar los textos bíblicos partiendo de sus lenguas originales» (Muñoz, 2016: s. p.).

En el caso de fray Luis de León, una importante prueba de cargo de la acusación fue la traducción del Cantar de los cantares que, según declaró ante el tribunal que lo juzgaba, había traducido del hebreo y comentado hacia 1561 a petición de Isabel de Osorio, prima suya y monja en el convento salmantino de Sancti Spiritus, y que un tiempo más tarde un joven fraile encargado de su celda (Diego de León) había copiado sin su permiso. La versión circuló en copias manuscritas y tuvo una gran difusión. El fraile agustino
Alonso de Gudiel, catedrático de Biblia en la Universidad de Osuna y acusado en un juicio paralelo al de los hebraístas salmantinos de defender el sentido literal de las Escrituras, tenía una copia hecha de su mano. Y una de las acusaciones contra Martín Martínez de Cantalapiedra fue haber utilizado en sus clases de Hebreo en 1560-1563 la traducción de fray Luis y minar la autoridad de la Vulgata (Sáenz Badillos, 1995: 168-169). Hay constancia de que la traducción llegó a Portugal e incluso al Nuevo Mundo. En su confesión ante el tribunal (León, 1991: 36), fray Luis alegó que había recibido un mensaje de aprobación del dominico lisboeta Francisco Foreiro, compilador en 1561 de un Índice portugués y en $1564 \mathrm{del}$ surgido de Trento. En Cuzco, el franciscano Pedro Quiroga, comisario de la Inquisición limeña, requisó en el convento de los agustinos de esa ciudad un ejemplar que a su vez había sido copiado en el monasterio de San Agustín de Quito (Alcalá, 1991: 595-597).

Fray Luis fue acusado por Bartolomé de Medina de 17 proposiciones no ortodoxas, la primera de las cuales era haber reducido el Cantar de los cantares a un vulgar poema de amor, «Canticum canticorum est carmen amatorium Salomonis ad filiam Pharaonnis» (León, 1991: 437). Se consideró que profanaba el texto al reducirlo a un mero canto de Salomón a su esposa y negar con ello su sentido alegórico, el privilegiado por la Iglesia. Fray Luis se defendió afirmando que solo había pretendido «declarar la corteza de la letra» (León, 1994: 47), ofrecer el sentido literal, como paso previo e imprescindible para captar su sentido espiritual. En ningún momento negó, pues, fray Luis la interpretación alegórica del Cantar, favorecida no solo por la tradición cristiana sino también por la judía, sino que pretendió ceñirse únicamente a su literalidad «como si eneste libro no vuiera otro mayor secreto del que muestran aquellas palabras desnudas» y no 
32 tocar el sentido espiritual «que del ay escritos grandes libros por personas santissimas y muy doctas» (León, 1994: 47-48).

Tras casi cinco años de cárcel, fue finalmente absuelto y liberado a finales de diciembre de 1576. Gaspar de Grajar había muerto en prisión tres meses antes, y Martín Martínez no recobró la libertad hasta junio de 1577. En 1573 había muerto en la cárcel Alonso Gudiel.

En su prólogo al Cantar, fray Luis distingue entre una traducción literal, coincidente en todo lo posible (idealmente, también en el número de palabras) con el original y abierta como él a la interpretación, y una traducción parafrástica, más explicativa y orientada a la lengua de llegada. En su versión se decanta por el primer enfoque, pero no considera excluyentes ambas aproximaciones, sino complementarias. También indica haber traducido desde el hebreo y consultado todas las traducciones griegas y latinas existentes (León, 1994: 51-52). No dice nada del cotejo con otras versiones hechas desde el hebreo, pero Sergio Fernández López (2007) ha señalado, tanto en la traducción del Cantar y como en la posterior del Libro de Job, la fuerte semejanza de la versión luisiana con algunos manuscritos bíblicos judeorromances.

Este hecho hablaría de una transmisión continuada, a pesar de las prohibiciones y persecuciones, de unos textos medievales que pudieron ser consultados por los humanistas incluso antes de que Arias Montano ocupara en 1577 el cargo de bibliotecario mayor de El Escorial y consiguiera reunir allí valiosas Biblias medievales, algunas de las cuales estaban en poder de la Inquisición (Fernández López, 2009: 76-78). Los humanistas debieron de conocerlas antes en la biblioteca de la Universidad de Alcalá, que albergaba los materiales utilizados en la preparación de la Biblia políglota complutense y, entre ellos, «Biblias antiguas [...] puntuales con el hebreo» procedentes de Toledo, según refirió fray José de Sigüenza (1544-1606), discípulo de Arias Montano y ayudante suyo en El Escorial (Sigüenza, 1853: 413). Fernández López (2007) ofrece pruebas textuales en apoyo de la tesis según la cual fray Luis probablemente contó con una Biblia judeorromance hoy perdida para elaborar su versión comentada del Cantar: son grandes las coincidencias con el manuscrito 10288 de la Biblioteca Nacional de España, que a su vez está relacionado con los manuscritos escurialenses E4 y E5. Esas coincidencias aparecen en la traducción del poema y en otras ocasiones, cuando esta se aleja del texto judeorromance, en su comentario.

Fray Luis realizó asimismo versiones de 24 salmos, tradujo y comentó en La perfecta casada (1583) el poema acróstico sobre la mujer virtuosa de Proverbios 31:10-31 y también tradujo el libro de Job, de modo literal junto con una explicación del argumento y en una versión endecasilábica en terceros encadenados ${ }^{24}$.

En relación con la traducción literal de Exposición del Libro de Job, Fernández López (2010) ha establecido, como en el caso del Cantar, una innegable dependencia con respecto a una traducción judeorromance, en ese caso, la Biblia de Ferrara. Algunos especialistas han identificado cambios estilísticos en el texto y los han atribuido a los avatares biográficos del autor (por ejemplo, Macrí, 1970: 39-40); ahora bien, esas diferencias (que permitirían una división en tres bloques textuales: capítulos 1-32, 33-35 y 36-42) podrían explicarse según la literalidad o la libertad con respecto a la versión sefardí. Esa servidumbre empañaría, por un lado, la originalidad de fray Luis; pero, por otro, constituiría un inesperado testimonio del conocimiento y uso clan-

\footnotetext{
${ }^{24}$ Existe también una versión del Cantar en liras y octavas reales que se le atribuyó en el pasado, pero esa atribución hoy se pone en duda.
} 
destino en territorio peninsular de la Biblia de Ferrara por parte de los humanistas españoles.

En apoyo de esta tesis cabría aducir también la traducción de los 22 versículos del poema de la mujer virtuosa de Proverbios 31, cuyo comentario da lugar a La perfecta casada. También en esos versos es posible percibir ese impulso literalista tradicionalmente achacado al intento de crear un «castellano bíblico» a partir del calco hebraísta y la interlinealidad (Alonso, 1977: 406 407), pero en relación con el cual no cabría descartar la influencia directa de alguna traducción judeorromance auxiliar que podría ser, como en el caso de Job, la Biblia de Ferrara (o alguna otra como la BNE 10822). El procedimiento es el mismo que en el Cantar: da la impresión de que la traducción introduce modernizaciones y que algunos alejamientos léxicos desaparecen luego en el comentario. Dado que se trata de un texto breve (22 versículos que utilizan las 22 letras del alfabeto hebreo), se presentan a continuación la versión de fray Luis y la de Ferrara en una yuxtaposición que ilustra el proceder comentado por Fernández López para el Cantar y Job.

\section{FRAY LUIS DE LEÓN}

10 Mujer de valor, ¿quién la hallará?

Raro y extremado es su precio.

Glosa: «O como dice el original en el mismo sentido:

"Más y allende, y muy alejado sobre las piedras preciosas, el precio suyo”...».

11 Confía en ella el corazón de su marido, no le harán mengua los despojos.

Glosa: «Llama despojos lo que en español llamamos alhajas y aderezo de casa, como algunos entienden, o, como tengo por más cierto, llama despojos las ganancias que se adquieren por vía de mercancías...».

12 Pagóle con bien y no con mal todos los días de su vida.

13 Buscó lana y lino, y obró con el saber de sus manos.

14 Fue como navio de mercader, que de lueñe trae su pan.

15 Madrugó y repartió a sus gañanes las raciones, la tarea a sus mozas. [gañanes: criados]

16 Vínole al gusto una heredad, y compróla, $y$ del fructo de sus palmas plantó viña.

17- Ciñóse de fortaleza y fortificó su brazo. Tomó gusto en el granjear;

19 su candela no se apagó de noche. Puso sus manos en la tortera, y sus dedos tomaron el huso.

[granjear: ahorrar; tortera: rodaja para retorcer la hebra en el huso]
BIBLIA DE FERRARA ${ }^{25}$

10 Muger de fonsado quien fallara? y lexos mas $q$ piedras preciosas su precio.

[fonsado: valor]

11 Confiose en ella coraçon de su marido: $y$ despojo no faltara.

12 Gualardonolo bien y no mal: todos los dias de sus vidas.

13 Requirio lana y linos: $y$ fizo con voluntad de sus palmas.

14 Fue como navios de mercader (que) de lejos trae su pan.

$15 Y$ alevantose en quanto noche: $y$ vio mantenimiento para su casa: $y$ costumbre de sus moças.

16 Penso campo y tomolo: de fruto de sus palmas planto viñas.

17- Ciñio con forteza sus lomos: $y$ enforcescio sus brazos.

19 Gustoo q buena su mercaderia: no se amatara en la noche su candela.

Sus brazos tendio en el buso: $y$ sus palmas sustentaran rueca.

25 El texto citado procede de la edición facsimilar preparada por Sociedad Estatal Quinto Centenario (Madrid, 1992). 
20 Sus manos abrió para el afligido, y sus manos extendió para el menesteroso.

21 No temerá de la nieve a su familia, porque toda su gente vestida con vestiduras dobladas.

22 Hizo para sí aderezos de cama; holanda y púrpura en su vestido.

23 Señalado en las puertas su marido, cuando se asentare con los gobernadores del pueblo.

24 Lienzo tejió y vendiólo; franjas dió al cananeo. Glosa: «Cananeo llama al mercader y al que decimos cajero..». [cajero: buhonero]

25 Fortaleza y buena gracia su vestido, reirá hasta el día postrero.

26 Su boca abrió en sabiduría, y ley de piedad en su lengua.

27 Rodeó todos los rincones de su casa, y no comió el pan de balde. Glosa: «que se entienda que su andar es su casa...».

28 Levantáronse sus hijos y loáronla, y alabóla también su marido.

29 Muchas hijas allegaron riquezas, mas tú subiste sobre todas. Glosa: «Hijas llama el hebreo a cualesquier mujeres...».

30 Engaño es el buen donaire y burlería la hermosura; la mujer que teme a Dios, ésa es digna de loor.

31 Dadle del fructo de sus manos, y lóenla en las puertas sus obras. Glosa: «Y así añade: "Y lóenla en las plazas sus obras". Porque mandar Dios que la loen, es hacer cierto que la alabarán...».
20 Su palma estendio al pobre: $y$ sus manos tendio a desseoso.

21 No temera a su casa de nieve: por que toda su casa vestida de grana.

22 Tapetes fizo a ella: de lino y purpura su vestido.

23 Conoscido en consejos su marido: en su estar con viejos de tierra.

24 Sabana fizo y vendio: $y$ cintero dio a mercader.

25 Forteza y hermosura su vestido: y reyra en dia postrimero.

26 Su boca abrio con sabiduria: $y$ ley de merçed sobre su lengua.

27 Especulan andaduras de su casa: y pan de pereza no comio.

28 Alevantaronse sus hijos bienaventuraronla: su marido y alabola.

29 Muchas dueñas fizieron aver: $y$ tu pujaste sobre todas ellas.

30 Falsedad la gracia y vana la fermosura: muger temien a. A. ella es alabada.

31 Dad a ella de fruto de sus manos: $y$ alabarlaan en consejos sus fechas.
En 1580, a instancias de su superior agustino (León 1992: X) fray Luis volvió al Cantar y publicó los comentarios del Cantar traducidos al latín y añadiendo además a su explicación literal una explicación mística. La obra se reeditó en 1582 y de nuevo en 1589, ampliada con un tercer sentido de tipo anagógico ${ }^{26}$ y con el título Triplex ex-

${ }^{26}$ Es el tercero de los sentidos espirituales de la Escritura. El actual Catecismo católico (artículo III, apartados 115-119) sigue recogiendo la antiquísima tradición de considerar la existencia de un sentido literal y tres sentidos espirituales. El anagógico, que complementa el alegórico y el moral, permite interpretar la letra en «su significación eterna... que nos conduce hacia nuestra Patria»; así, la Iglesia es el signo de la Jerusalén celeste. planatio in Canticum Canticorum (León, 1992). En el prólogo de esa edición, fray Luis declara que la publica «coaccionado», convencido de que «en este nuestro tiempo la tarea de escribir [...] no es muy útil para los demás y es demasiado peligrosa para los que escriben» (León, 1992: 12-13).

Tras la transgresión que supuso la difusión de copias manuscritas con una versión literal castellana donde el Cantar se presentaba como una «égloga pastoril» (León, 1994: 48), la publicación de ese libro y su reedición ampliada señala claramente el límite de lo permitido dentro de la ortodoxia contrarreformista. El libro es, en cierto 
sentido, la antítesis de la versión manuscrita. De entrada, toda la obra está escrita en latín. Además, el texto bíblico que se sigue es el de la Vulgata y no el hebreo, que solo se añade para explicar algunos puntos oscuros. Y, por último, si a la explicación inicial del sentido literal (que llamó «sobrehaz», «corteza»y «sonido») superpuso fray Luis en 1580 una segunda explicación con una plantilla interpretativa según la cual Salomón es Dios, y su esposa, el alma cristiana («debaxo desemejança devna amorosa y pastoril Égloga [Salomón] nos da a entender quáles sean los effectos que el diuino amor produze en aquellos que desus son encendidos» (Becerra, 2003: 248)), luego, en 1589, añadió una tercera «exposición» aclarando el sentido verdadero del poema, los amores de Cristo y su Iglesia (León, 1991: 70):

la verdadera sentencia sin duda es que en este libro no se refiere la historia de ninguna conversación amatoria tenida en realidad por Salomón con su mujer o con alguna mujer, sino que su sentido histórico es místico y gira todo él en la expresión de cuanto la Iglesia y Cristo se amen entre sí, a los cuales Salomón introduce bajo las personas de cónyuges amantes entre sí y revelándose sus calores con suavísimas palabras ${ }^{27}$.

Ni la versión castellana del Cantar ni la de Job se publicaron en vida de fray Luis. Esos textos permanecieron inéditos durante dos siglos. La Exposición del Libro de Job se publicó finalmente en 1779 en una edición que unía dos manuscritos, uno con la traducción literal y el comentario en prosa, y otro con un resumen argumental de cada capítulo y la versión parafrástica en tercetos. En algunos lugares donde faltaban, los argumentos y los tercetos fueron suplidos por el poeta agustino fray Diego González (1733-1793). La Traduc-

\footnotetext{
${ }^{27}$ Para un lector contemporáneo, resulta difícil no percibir en esa frase procedente del inicio de la tercera explicación los ecos anticipados de la abjuración galileana.
}

ción literal y declaración del libro de los Cantares de Salomón se publicó dos décadas después, en 1798.

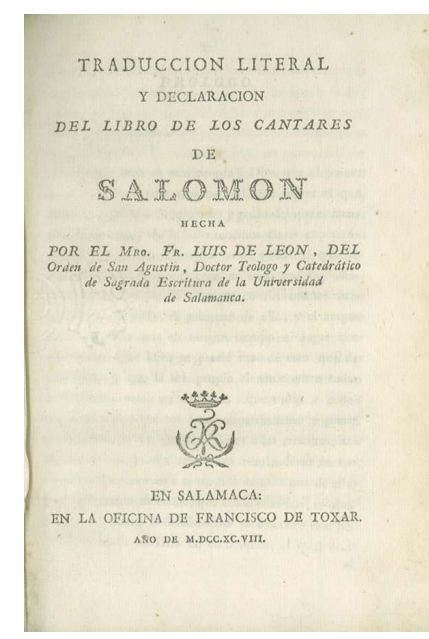

IMAGEN II. Portada de la primera edición impresa
del Cantar de los cantares (1798) de fray Luis de León

El caso de fray Luis de León es el más conocido y se ha presentado aquí con valor representativo en tanto que figura señera del biblismo hispano de los obstáculos alzados ante quienes se enfrentaron en la península a la tarea de la traducción bíblica. Similar suerte corrieron versiones de distintas partes de la Biblia realizadas por otros autores y que no pudieron publicarse contemporáneamente: Juan de Robles (ca. 1492-1572), benedictino de Montserrat, realizó y anotó (entre 1545 y1558) una Nueva traslación e interpretación española de los cuatro sacrosantos Evangelios de Jesu Christo, que se publicaría sin comentarios en 1906 28 ; el dominico fray Luis de Granada (15041588), que murió en el exilio de Portugal, tradujo

${ }^{28}$ Hélène Rabaey (2015) ha estudiado la defensa de la traducción hecha por Robles, así como el propósito y las fuentes de su versión anotada (hecha a partir de la Vulgata); también ha editado (2018) el prólogo de la obra. 
varios fragmentos bíblicos, entre ellos los Salmos (ca.1580), publicados en 1801; el monje jerónimo José de Sigüenza (1544-1606), sucesor de Arias Montano al frente de la biblioteca del Escorial, llevó a cabo una traducción de los Evangelios titulada La Historia del Rey de Reyesy Señor de los Señores Cristo Señor nuestro, que sigue inédita.

Es cierto que algunas versiones parciales fueron permitidas, como también se permitió la traducción de fragmentos con las anotaciones o glosas pertinentes o incluidos en otras obras piadosas (categoría en la que caería, por ejemplo, La perfecta casada), así como la lectura, previa concesión de una licencia (un requisito que no estaba al alcance de cualquiera y al que debían someterse incluso personajes de alta alcurnia ${ }^{29}$. A lo largo de la primera mitad del siglo se reimprimieron en diversas ocasiones la recopilación de lecturas litúrgicas del Nuevo Testamento y sermones Epistolas y Evangelios por todo el año que sería atribuida a Ambrosio Montesino (Matesanz, 1997) ${ }^{30}$; o, a veces fuera de la península, algunos libros concretos, como las versiones de los Salmos, siempre el libro más traducido y leído: el Psalterio de Gómez de Santo Fimia (Lisboa, 1529); el Arpa de David, versión glosada del benedictino de Montserrat Benito Villa (Barcelona, 1540; Medina del Campo, 1545) y que acabó en el Índice; el Psalterio de David, traducción de Rodrigo Manrique (discípulo de Luis Vives) de la paráfrasis latina de Rainer Snoy de Gouda (Amberes, 1555). El Psalterio también fue

${ }^{29}$ Fernández López (2003: 115-116) cita un documento de 1543 mediante el cual se concedía licencia de un año para leer una Biblia en lengua vulgar toscana a la duquesa de Soma.

${ }^{30}$ Se publicó desde 1506 hasta su prohibición en el Índice de 1559; luego se permitió a partir de 1586 y volvió a ser incluida en el Índice de 1612. Montesino revisó (1512) por petición de Fernando el Católico la traducción existente de la obra, de autor desconocido, para eliminar elementos judaizantes y ajustarla mejor a la ortodoxia católica. La obra le sería luego atribuida. imprimido por Sebastián Grypho (Lyon, 1550), junto con versiones anónimas de Job, Proverbios y Eclesiástico (Bataillon, 1966: 556).

Las prohibiciones se recrudecieron con el nombramiento de Fernando Valdés como inquisidor general en 1547. De todos modos, tras la publicación de su Índice de 1551 (que prohibió la traducción de la Biblia, sin especificar libros concretos), algunas versiones parciales siguieron circulando un tiempo hasta que se clarificó su prohibición (Fernández López, 2003). Fueron básicamente, algunos libros sapienciales (Salmos, Job, Proverbios, Eclesiático), evangelios y epístolas. Así, en Amberes, la «ciudad fuera de España en la que se editó un mayor número de obras en castellano en el siglo XVI» (Moll, 2000: 118), el impresor Martin Nucius obtuvo en 1543 privilegio imperial para imprimir en Flandes una obra con siete salmos penitenciales, quince graduales y las Lamentaciones de Jeremías en traducción de la Vulgata de Hernando de Jarava por encargo de Leonor de Autria, reina de Francia y hermana de Carlos V, de quien era capellán. La obra se reimprimió en 1546 y 1556 y fue prohibida en el Índice de 1559. De Jarava también publicó Nuncius en 1550 Liciones de Job con los nueve salmos, prohibida en el Índice de 1551 (Agten, 2018). El Índice de 1559, al que precedió el año anterior una gran quema de libros en Valladolid, dejó claro que la prohibición incluía la Biblia toda ella, sus partes y también a sus lectores. Las traducciones bíblicas al castellano solo pudieron entonces circular y ser leídas libremente fuera del alcance de la Inquisición.

El territorio de la monarquía hispánica no fue durante el siglo Xvi propicio para que prosperaran libremente en él la traducción y la lectura de los textos bíblicos en lengua vulgar. Aunque, como señala Wim François (2018: 50), frente al rigor inquisitorial ejercido en España contra conversos, alumbrados y protestantes, 
Carlos V mostró una mayor tolerancia hacia el humanismo bíblico en los Países Bajos (como pone de manifiesto, por ejemplo, el mencionado permiso para imprimir las versiones de Jarava). Y es cierto que hubo fisuras en la capacidad del poder establecido, como señala García Pinilla (2020: 82-83), para impedir la circulación de los materiales bíblicos.

En cualquier caso, la primera traducción al castellano que contó en España con el beneplácito de las autoridades esclesiásticas solo vio la luz, hecha a partir de la Vulgata por los escolapios Felipe Scío de San Miguel y Benito Feliú de San Pedro, dos siglos más tarde (1790-1793), más de treinta años después de que el papa Benedicto XIV revocara en 1757 la prohibición tridentina (Sánchez Caro, 2007: 408). En el siglo XVI, los protagonistas del impulso por la traducción de los textos bíblicos y su lectura en vulgar fueron, básicamente, no católicos que no siempre pudieron escapar de la persecución religiosa. Los traductores pertenecieron a dos grandes diásporas, la judía y la protestante.

\section{LAS BIBLIAS DEL EXILIO: LA DIÁSPORA JUDÍA}

Una parte importante de los judíos expulsados de Castilla y Aragón (1492), Portugal (1497), Navarra (1498) y Nápoles (1541) buscaron refugio en tierras más orientales en las que poder vivir y practicar de un modo más libre su religión. A grandes rasgos, cabe distinguir una diáspora oriental y una diáspora occidental, y ambas dejaron un valioso testimonio bíblico impreso.

De la diáspora oriental, establecida en los territorios levantinos bajo dominio del imperio otomano y acogida por el sultán Bayaceto II y sus sucesores (entre ellos, Solimán I el Magnífico), se conocen hasta la fecha 14 ediciones bíblicas pu- blicadas a lo largo del siglo XVI hasta 1600, todas ellas aljamiadas (Cohen, 2019: 201). Los principales centros editoriales fueron Constantinopla y Salónica. El testimonio más antiguo conservado es un fragmento de Daniel impreso en Salónica (ca.1515) y descubierto recientemente por Dov Cohen entre los materiales de la Genizá de El Cairo, que se adelanta en tres décadas a la traducción de los Salmos realizada en Constantinopla (ca.1545), considerada durante mucho como la más antigua. La traducción más famosa es el Pentateuco de Constantinopla (1547), que contiene la primera Torá aljamiada en judeoespañol.

En el ámbito occidental, la traducción más importante e influyente es la Biblia de Ferrara (1553), impresa en ese ducado del norte de Italia gobernado hasta finales del siglo por la Casa de Este.

\section{Pentateuco de Constantinopla}

El llamado Pentateuco de Constantinopla (1547) es, en realidad, una edición políglota de la Torá publicada por Eleazar Soncino, impresor de los Salmos mencionados. Eleazar pertenecía a la cuarta generación de una familia de impresores procedentes del norte de Italia que se asentaron en diferentes partes del imperio otomano. Establecido en Constantinopla en 1534, acababa de imprimir en 1546 otro Pentateuco políglota en hebreo, arameo, persa y árabe.

En el Pentateuco de 1547, el texto está presentado en tres columnas principales. El texto masorético hebreo aparece en el centro en cuerpo mayor, flanqueado en un cuerpo más pequeño por la traducción judeoespañola en el interior de la página y la judeogriega en el exterior. Sobre ellas, el Targum de Onquelos en arameo (leído en la liturgia) y, en la parte inferior de la página, en hebreo, el comentario de Rashí, ambos en letra más pequeña aún. La portada proclama la doble 
38 intención, pedagógica y litúrgica, del libro (Bádenas y Sznol, 2013: 123):

Loor al Eterno que nos ha incitado / a imprimir un libro «todo él delicias»: los cinco / libros de la Ley, escritos en escritura hebrea, con las Haftaroth / y las cinco Megilloth. Y para hacerlo útil al joven hijo de Israel y [que] / sus lenguas se apresuren a hablar correctamente, hemos considerado oportuno imprimir / en él la traducción de la Escritura en lengua griega y lengua sefardí, las dos / lenguas habituales entre los hijos de nuestro pueblo en este amargo destierro, nobles de Judá e Israel que habitan en las tierras / de Turquía. Y por estar todo hijo de Israel obligado / a completar sus perícopas (parasha) con la comunidad — dos veces el versículo y una vez el Targum - / hemos optado también por imprimir en él también el Targum, / Onqelos y el comentario de Rashí — sobre él sea la paz-. [Traducción de Elena Romero y Pedro Bádenas de la Peña].

Esta declaración explicita que la obra estaba específicamente dirigida a los fieles locales y cumplía una función de consolidación de las distintas comunidades judías de Constantinopla. El análisis llevado a cabo por Lorenzo Amigo (1990) puso de relieve la radicalidad del proceso de traducción. Comparado con el manuscrito escurialense E7, del siglo XIV, Amigo concluyó que el Pentateuco de Constantinopla parecía casi más arcaico. La traducción palabra por palabra, manteniendo la categoría gramatical, y donde cada término debe cubrir el campo semántico del hebreo socava la inteligibilidad: «aunque el léxico es el castellano, [la semántica] está vista bajo el prisma del hebreo»y «la sintaxis atormentada [del Pentateuco de Constantinopla] de ninguna manera se puede considerar castellana» (1990: $138,139)$. Dicho proceder la entronca con la tradición de traducción reverencial ante el hebreo, la lengua hablada por Dios, que nació con las versiones griegas de la Septuaginta (siglo III a. C., la primera traducción de un texto sagrado en

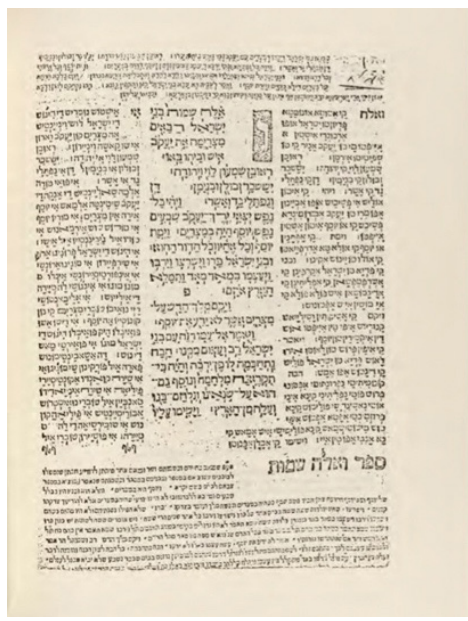

\section{IMAGen I2. Principio del Éxodo en el Pentateuco de Constantinopla (1547)}

Occidente) y la de Aquila (siglo II), un impulso distorsionador de la lengua común en pos de una lengua sacra que, por ejemplo, también es visible en el seno del cristianismo en la versión griega del Eclesiástico hecha por Jesús ben Sira (siglo II) que está incluida en el canon católico y ortodoxo o en la versión latina de Jerónimo de Estridón (siglos IV-v).

Junto con la Biblia de Ferrara, el Pentateuco de Constantinopla se ha visto (Fernández Marcos, 1985: 197) como la «culminación de una serie de traducciones medievales en lengua vulgar [...] que incorporaba a la vez una tradición exegética cuyos máximos representantes eran Abrahán Ibn Ezra de Toledo (1089-1167) y Moše ben Naḥman (Naḥmánides) de Gerona (1194-1270)».

\section{Biblia de Ferrara}

La Biblia de Ferrara, por su parte, vio la luz seis años después en el otro extremo del Mediterráneo, en el Estado homónimo donde la tolerante política de la Casa de Este hizo florecer la comu- 
nidad sefardí más importante de Italia. Escrita en caracteres latinos, tuvo una repercusión incomparablemente superior: además de la primera edición ferrarense, se realizaron en los dos siglos siguientes seis reediciones completas, nueve del Pentateuco y cuatro de los Salmos (Boer, 1994:252).

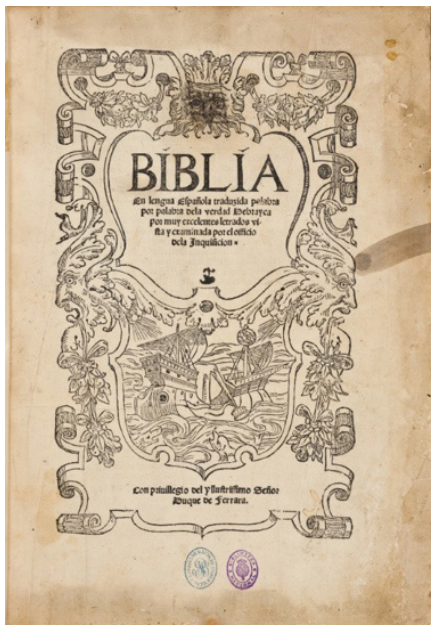

IMAGEN I3. Portada de la Biblia de Ferrara (1553)

Contiene toda la Biblia hebrea y fue el primer Antiguo Testamento impreso en castellano. Bajo la imagen de lo que parece ser una coca de tres mástiles con el palo mayor roto en medio de una tormenta ${ }^{31}$, la portada anuncia: «Biblia / En lengua Española traduzida palabra / por palabra dela verdad Hebrayca / por muy excelentes letrados vis- / ta y examinada por el officio / de la In-

${ }^{31}$ Doris Moreno ofrece en su biografía de Casiodoro de Reina (2017) la imagen de una pintura mural del patio de los Evangelistas del convento de San Isidoro de Sevilla. Curiosamente, se trata también de una coca mediterránea en situación comprometida, zarandeada por las olas y flanqueada por unas figuras diabólicas que la acechan a ambos lados. El mástil es un árbol en cuya copa hay dos hileras de figuras: en la superior, están el papa y sus eclesiásticos; en la inferior, el rey sus cortesanos. Dos ratas roen la base del mástil. quisición». Los responsables de la edición fueron un importante mercader llamado Yob Tob Atías (Jerónimo de Vargas) y el tipógrafo Abraham Usque (Duarte Pinel), dos conversos vueltos al judaísmo a quienes en ocasiones se cita erróneamente como traductores de la obra. Suele mencionarse asimismo la existencia de dos ediciones, una «cristiana» y otra «judía». En realidad, la edición es la misma (Segre, 1994: 206, 219-220), salvo que en algunos folios presenta una dualidad en dos elementos paratextuales: la dedicatoria y el colofón. Unos ejemplares están dedicados a Hércules II de Este, duque de Ferrara, Módena y Reggio, «debaxo de cuyo sublime favor navegaremos seguros por el tempestuoso mar que las detractoras lenguas puedan levantar», según afirma el texto; $y$ otros lo están a Gracia Nasí (Hannah Nasí, Beatriz Luna, Gracia Mendes), poderosa mujer de negocios portuguesa establecida en Ferrara e importante protectora de los judíos ${ }^{32}$. En el colofón de la versión «cristiana», se dice que la obra se acabó «con yndustria y de-

32 Gracia Nasí (Beatriz Luna, según su nombre cristiano) nació en Lisboa en 1510 en el seno de una familia judía establecida en Portugal tras 1492 y convertida al cristianismo en 1497, como consecuencia de la orden de Manuel I dada a los judíos de convertirse o abandonar el país sin sus hijos. (Isabel, viuda de Juan II de Portugal e hija de los Reyes Católicos, puso esa condición para aceptar el matrimonio con el sucesor al trono, Manuel I.) Gracia se casó en 1528 con su tío Francisco Mendes, un rico comerciante de especias y piedras preciosas y también banquero, criptojudío como ella. En 1536, tras el establecimiento de la Inquisición en Portugal, Mendes planeó abandonar el país pero murió en 1537. Viuda $\mathrm{y}$ al frente de un poderoso imperio económico europeo, se trasladó ese año a Amberes; luego lo haría a Venecia y Ferrara y más tarde a Constantinopla. Fue una de las mujeres más ricas y poderosas de la época. Creó una red europea de huida de la Inquisición y, una vez en el imperio otomano, intentó fundar un hogar judío en tierras palestinas. Murió en Constantinopla en 1569. Una interesante biografía: The Long Journey of Gracia Mendes, de Marianna D. Birnaum (Budapest: Central European University Press, 2003), disponible en https://books.openedition.org/ceup/2123. 
ligencia de Duarte Pinel portugués» y «a costa y despesa de Jerónimo de Vargas español el primero de março de 1553»; en la versión «judía», ambos son mencionados con sus nombres judíos y se ofrece la fecha según el calendario hebreo: «con yndustria y deligencia de Abraham Usque portugués, estampada a costa y despesa de Yom Tob Atías hijo de Leví Atías español, en 14 de adar de 5313». Iacob Hassán (1994: 48) ha hecho notar la no coincidencia de las fechas, puesto que, al parecer, el 14 de adar (fiesta de Purim) correspondió al 28 de febrero de 1553, lo cual parecería conceder cierta preeminencia temporal de una versión sobre la otra (o sencillamente se quiso aprovechar la coincidencia y colocar la impresión bajo el amparo de una festividad que celebra la supervivencia milagrosa del pueblo judío ante un intento de exterminio).

En relación con la autoría de la traducción, la obra no menciona ningún nombre concreto. El prólogo introductorio (anónimo) afirma que se procuró seguir en la medida de lo posible la traducción de Santes Pagnino por ser «tan conforme a la letra hebrayca», que se consultaron «todas las trasladaciones antiguas y modernas y de las hebraycas las más antiguas que de mano se pudieron hallar» y que se procuró siempre la ayuda de «muy sabios y experimentados letrados en la misma lengua assí hebrayca como latina»; de modo similar, el colofón vuelve a insistir en que fue traducida «por muy excelentes letrados». El texto ha sido emparentado con los romanceamientos del siglo XIV y en concreto con el manuscrito escurialense E3 (Lazar, 1994).

El lenguaje utilizado sigue las estructuras del hebreo menos rígidamente que en el caso del Pentateuco de Constantinopla y guarda con el castellano mayor parecido que él (no tanto en la sintaxis, pero sí en el léxico), aunque no deja de presentar dificultades a los lectores contemporáneos por su recurso a una sintaxis hebrea combinada con rasgos gramaticales y léxicos del castellano medieval. El propio prólogo advierte:

Y aunque a algunos paresca el lenguaje della bárbaro y estraño y muy differente del polido que en nuestros tiempos se usa, no se pudo hazer otro porque queriendo seguir verbo a verbo y no declarar un vocablo por dos (lo que es muy dificultoso) ni anteponer ni posponer uno a otro, fue forçado seguir el lenguaje que los antiguos hebreos españoles usaron, que aunque en algo estraña, bien considerando hallarán tener la propiedad de vocablo hebrayco y allá tiene su gravedad que la antigüedad suele tener.

La declaración afirma claramente la voluntad de recrear mediante el forzamiento lingüístico y el calco sintáctico una lengua litúrgica dotada de la gravedad de lo antiguo. Y ese efecto de extrañamiento fruto de la voluntad literalista y el impulso por forjar una lengua litúrgica que buscaba un menor alejamiento de la lengua santa producía un extrañamiento que no dejaría de crecer con el tiempo. Así, en 1772, se publicaría en Leiden en castellano una paráfrasis de los profetas mayores (Fernández Marcos, 1994: 450). Se ha considerado (Bunis, 1994: 343-344) que esas características reflejan

la orientación lingüístico-literaria de los ex marranos en Europa occidental, quienes a su vuelta al judaísmo se mantuvieron lingüísticamente diferenciados de sus hermanos sefardíes no marranos como resultado de su parcial apertura a la lengua y las tradiciones culturales cristianas, pero también de los propios españoles cristianos por su oposición a abandonar completamente su herencia lingüística judía.

Los elementos paratextuales también contienen un intento de ocultar el verdadero público destinatario de la traducción bajo un manto de ortodoxia cristiana: «con el privilegio del yllustrissimo Señor Conde de Ferrara» y «vista 
y examinada por sus letrados y ynquisidor [...] complidamente», se afirma en la portada y en la dedicatoria a Hércules II. A diferencia de lo que ocurría en el Imperio otomano, los sefardíes occidentales se encontraban en una situación mucho más precaria en el seno de la sociedad cristiana, mucho menos tolerante en términos confesionales que la musulmana de Levante. Sin embargo, los datos ofrecidos no falsean la realidad: la aprobación ducal existió, como también el beneplácito de la censura local ${ }^{33}$.

Frente a quienes han visto (Lazar, 1994) en la Biblia de Ferrara y en el Pentateuco de Constantinopla una culminación del linaje de romanceamientos medievales peninsulares que incorporaban una tradición exegética sefardí cuyos máximos representantes fueron, como se ha mencionado más arriba, el tudelano Abraham ibn Ezra y el gerundense Moshé ben Nahmán, otros estudiosos han hecho hincapié en las diferencias detectables entre el Pentateuco de Constantinopla y la Biblia de Ferrara y los romanceamientos bíblicos realizados durante la Edad Media en la península ibérica. A partir de la conservación de la sintaxis castellana en las antiguas Biblias romanceadas y la literalidad extrema a la semántica y la gramática del hebreo en las Biblias ladinadas, Amigo (1990: 112-113) se ha inclinado por la existencia de tradiciones paralelas: «Las traducciones romanceadas y ladinadas aparecen ante nosotros como si se tratara de un proceso creciente de literalismo, pero es muy posible que hayan coexistido históricamente, pero no se hayan conservado traducciones en ladino anteriores al siglo XIV».

Por su parte, Ora Schwarzwald (2010) ha comparado diversos manuscritos escurialenses

33 El inquisidor de Ferrara, el dominico Girolamo Papino da Lodi, tenía fama de indulgencia y condescendencia con los deseos del duque (Segre, 94: 213). y la Biblia de Alba con el Pentateuco de Constantinopla y la Biblia de Ferrara. A partir del análisis del nombre de la divinidad (la palabra Dios no aparece en Constantinopla ni Ferrara), la traducción de los nombres propios y, sobre todo, las características sintácticas de las traducciones, concluyó que las dos obras posexílicas reflejan una tradición independiente, también antigua, pero dependiente de la traducción oral palabra por palabra usada en la sinagoga. El escaso literalismo sintáctico de las Biblias en romance, ha llevado a Schwarzwald a negar la naturaleza judía de esas biblias preexílicas. Desde esa perspectiva, quedaría zanjada la cuestión de una posible división de las Biblias romanceadas según un uso judío o un uso cristiano. Todas las peninsulares serían de uso cristiano, como también afirman Bádenas y Sznol (2013: 128): «Las traducciones escritas, llamadas traducciones judías romanceadas, fueron realizadas por autores judíos invitados por un patrón cristiano».

La diferencia en relación con el grado de servilismo respecto al hebreo que muestran el Pentateuco de Constantinopla y la Biblia de Ferrara se explica por el diferente público de las dos obras, como ya se ha señalado (Bunis, 1994), los lectores del primero salieron de la península ibérica y nunca renunciaron a su fe judía, mientras que los de la segunda eran, por así decirlo, «retornados», judeoconversos o descendientes de judeoconversos que abandonaban el cristianismo para volver a la religión de sus mayores. Así, la Biblia de Ferrara se convirtió en un poderoso instrumento de rejudeización entre las comunidades sefardíes occidentales. Muchas de ellas la adoptaron con fines docentes y litúrgicos. Hay testimonios en ese sentido citados por Fernández López (2020) entre los judíos portugueses durante el siglo XVII y en el sur de Francia hasta el siglo XVIII. Y los datos sobre sus múltiples reediciones totales o parciales constituyen una prueba irrefutable de su 
42 uso continuado durante los dos siglos siguientes: la última reedición es de 1762 (Boer, 1994).

Ahora bien, como en el caso de la Políglota de Arias Montano, la Biblia de Ferrara logró traspasar (a pesar de sus dificultades lingüísticas) los límites confesionales del público al que iba realmente dirigido. Más allá de las comunidades sefardíes, fue leída y usada por públicos cristianos contemporáneos y posteriores y su huella puede discernirse en obras literarias y religiosas. Casiodoro de Reina la utilizó y la elogia en su Amonestación al lector: «De la vieja traslación española del Viejo Testamento, impresa en Ferrara, nos hemos ayudado en semejantes necesidades más que de ninguna otra que hasta ahora hayamos visto». Como se ha mencionado más arriba, Fernández López (2007 y 2011) ha señalado que fray Luis de León la copió literalmente en su traducción de Job; y también ha encontrado pruebas de su circulación en la península ibérica en expedientes inquisitoriales de principios del siglo XVII. Asimismo, es sabido que Quevedo (1580-1645) usó la Biblia de Ferrara, en su reedición amberiense de 1611, para traducir y comentar el primer capítulo de Jeremías, sus Lágrimas de Hieremías castellanas (1613), una obra en la que el escritor defendió la Vulgata utilizando paradójicamente como base una traducción hebrea (Fernández Marcos y Fernández Tejero, 2002: 315). Por otra parte, Quevedo también consultaría para su versión del primer capítulo del Cantar la versión comentada de fray Luis, dependiente de las Biblias romanceadas.

\section{BIBLIAS DEL EXILIO: LA DIÁSPORA PROTESTANTE}

El otro gran grupo de heterodoxos religiosos que se vio obligado a salir de la península ibérica en un intento casi nunca plenamente conseguido de eludir la persecución por motivos religiosos es el de los heterodoxos cristianos, básicamente protestantes, aunque alguno, como Juan de Valdés, nunca rompió de modo abierto con la Iglesia católica. Fueron pensadores que, llevados por el impulso de la reforma doctrinal, consideraron un deber traducir las Escrituras al castellano y arriesgaron su vida en la tarea. Su obra solo pudo ser leída clandestinamente en la península.

En la historia de las primeras traducciones bíblicas que se imprimieron en castellano desde una perspectiva reformista en el siglo xvI, una línea une los nombres principales de Juan de Valdés, Francisco de Enzinas, Juan Pérez de Pineda, Casiodoro de Reina y Cipriano de Valera. Aunque fueron todos ellos disidentes, presentaron entre sí notables diferencias doctrinales y se situaron en distintos lugares en el eje definido por el polo de la Reforma instituida (luteranos, calvinistas y anglicanos) y el polo de un «espiritualismo» de cuño erasmiano, por usar los términos de Jorge Bergua (2006: 210). También por la diferente importancia que concedieron a las cuestiones dogmáticas. Juan de Valdés, un erasmista muy marcado por el alumbradismo que nunca abandonó nominalmente el catolicismo, enfatizó la iluminación interior como fundamento de la fe. Francisco de Enzinas se inclinó también por el «espiritualismo» aunque mantuvo buenas relaciones con los grandes reformadores. Tampoco Casiodoro de Reina se encastilló en posiciones doctrinales y se movió en un terreno compartido entre el calvinismo y el luteranismo intentando eludir la polémica dogmática. Pérez de Pineda y Cipriano de Valera, en cambio, fueron decididamente calvinistas.

\section{Juan de Valdés}

De ascendencia conversa, Juan de Valdés (¿1495?1541) fue, junto con su hermano gemelo Alfonso (1495?-1532), secretario de Carlos V, uno de los 
grandes representantes del erasmismo español ${ }^{34}$. Estuvo durante su juventud al servicio de Diego López Pacheco, marqués de Villena, y en su pequeña corte entró en contacto con las ideas de los alumbrados. Valdés abandonó ese entorno tras la detención en 1524 de Pedro Ruiz de Alcaraz, uno de los principales representantes del alumbradismo y predicador protegido del marqués. Estudió en la Universidad de Alcalá, donde vivió el clima erasmista permitido todavía en la década de 1520. Allí publicó anónimamente en 1529 el catecismo Diálogo de doctrina cristiana, impreso por Miguel de Eguía ${ }^{35}$. El librito, descubierto por Marcel Bataillon en 1922 en Lisboa, es un comentario sobre la catequesis cristiana con el añadido de la traducción de los capítulos del Evangelio de Mateo que contienen el Sermón de la Montaña y las Bienaventuranzas. Según José C. Nieto (1979: 195), la obra «se encuentra a la vanguardia de toda la literatura de catequesis que la Europa del siglo XVI, bajo el impacto de la Reforma, iba a producir». El libro fue prohibido a los pocos meses de su aparición; los inquisidores consideraron que contenía ideas heréticas y procedieron a abrir una indagación sobre su autor (rápidamente identificado) ${ }^{36}$. Ahora bien, jamás se sospechó que bajo su apariencia erasmiana la obra contenía partes que, según detectó Carlos Gilly (1982: 88 y ss.), eran

34 La cuestión de los orígenes conversos de los Valdés ya ha quedado zanjada, así como el hecho de que Juan y Alfonso fueron gemelos. Un hermano de la madre fue quemado en 1491 por judaizante (Jiménez Monteserín, 2013: 160-173).

35 Continuador de la labor editorial emprendida por su suegro Arnao Guillén de Brocar y gran divulgador de las obras de Erasmo, Miguel de Eguía sería detenido por la Inquisición en 1530, en la campaña de represión antierasmista que se inició aquel año con la detención de Bernardino de Tovar. Permaneció en la cárcel dos años antes de ser liberado sin cargos.

${ }^{36}$ Se publicó en enero de 1529 y una carta del Consejo de la Suprema Inquisición a los tribunales de distrito prohíbe la obra y reclama su incautación en agosto de ese mismo año (Jiménez Monteserín, 2013: 187-188). traducción y adaptación de escritos de Lutero (además de Ecolampadio y Melanchthon). Se trataría, pues, de la primera presentación de las ideas de Lutero en castellano.

En cualquier caso, Valdés, que ya había sido objeto de inquisición con motivo del proceso a Ruiz de Alcaraz, juzgó prudente trasladarse a Italia, primero a Roma donde obtuvo el puesto de secretario del emperador y chambelán del papa Clemente VII (Médicis) ${ }^{37}$ y luego, tras el acceso al trono pontificio de Paulo III (Farnesio), a Nápoles (1535), donde halló residencia más segura en el entorno de la aristócrata Julia de Gonzaga ${ }^{38}$, que convirtió su palacio en un centro cultural y de protección a las ideas renovadoras, aunque manteniéndose siempre en el seno del catolicismo. Valdés nunca regresaría a la península ibérica.

En Nápoles, compuso para la noble italiana obras de exégesis cristiana y realizó traducciones parciales de la Biblia, si bien no publicó ningún escrito en vida, durante la cual siguió una actitud nicodemítica, de disimulo y prudencia. Tras

37 Con esos cargos se menciona en un salvoconducto citado por José C. Nieto (1997: 238) expedido por el papa en 1532 para que pudiera desplazarse al encuentro de su hermano, quien moriría en Viena, víctima de la peste, tres días antes de su llegada.

$3^{8}$ Julia de Gonzaga (1513-1556), viuda del duque Vespasiano Colonna y condesa de Fondi, había trasladado su corte a Nápoles en 1534, después de una sangrienta incursión del pirata Barbarroja contra Fondi con la que había pretendido raptarla y llevarla cautiva a la corte de Solimán. De ella y de su relación con Juan de Valdés, Menéndez Pelayo, escribió que «en el esplendor de su juventud y riqueza se alejó de las pompas y vanidades del mundo para dedicarse a la caridad y a la devoción. Entonces tuvo la desgracia de encontrarse con nuestro paisano, que fue para ella a modo de un director espiritual, cuyos consejos siguió ciegamente» (1992: 1, 1133). Menéndez Pelayo se burla del ascetismo de Valdés: a su recomendación acerca de la vida cristiana («Consiste la vida cristiana [...] en no ver lo que deleita tus ojos, en no oír lo que da placer a tus oídos»), replica que, sin embargo, «Valdés veía y oía a Julia Gonzaga y a Victoria Colonna, que no eran lo peor que podía verse y oírse» $(1992: 2,1149)$. 
su muerte, se imprimió en 1545 una traducción italiana del Alfabeto christiano, obra escrita (en 1536) en forma de diálogo con Julia de Gonzaga cuyo original castellano se ha perdido y en la que Gilly también detectó fragmentos traducidos de Lutero (1982: 91-92). Aunque Valdés no se adscribió, como se ha dicho, a ninguna corriente reformada, se lo considera un heterodoxo radical (Gilly, 2005) o, en la tipología de George Willams (1962), un representante de la Reforma radical, como Miguel Servet o Sébastien Castellio ${ }^{39}$.

A partir de 1542, tras el establecimiento de la Inquisición romana, la persecución de los discípulos de Valdés llevó a algunos de ellos a abandonar la península itálica y abrazar abiertamente el protestantismo. Sus escritos llegaron de ese modo a Juan Pérez de Pineda, quien publicó en Ginebra (con pie de imprenta falso: Venecia, Juan Philadelpho) la traducción comentada de la Epístola a los romanos (1556) y la traducción comentada de la Primera epistola a los corintios (1557), ambas realizadas a partir del griego, pero la primera también con el texto latino. En cambio, su versión del Salterio y su versión comentada del Evangelio según san Mateo no se publicaron hasta $1880^{40}$.

Valdés explicita en el prólogo a los Salmos su proceder a la hora de abordar como traductor un texto inspirado: afirma haber forzado el castellano cuanto ha podido para amoldarlo al hebreo, «pareciendome cosa conveniente y justa que las

\footnotetext{
39 Williams denominó «Reforma radical» a la corriente reformista formada por el anabaptismo, el espiritualismo y el racionalismo evangélico (tendencias de corte irenista, partidarias de la excomunión como única forma de coerción y de una vuelta al cristianismo primitivo), en tanto que opuesta a la «Reforma magisterial» (o «magistral») de luteranos, calvinistas y anglicanos, con Iglesias estructuradas e imbricadas en el poder civil.

$4^{\circ}$ Tampoco se publicaría de modo contemporáneo su única obra de carácter profano, el Diálogo de la lengua, sino que se encargaría de hacerlo más de dos siglos después, en 1777, el ilustrado Gregorio Mayans.
}
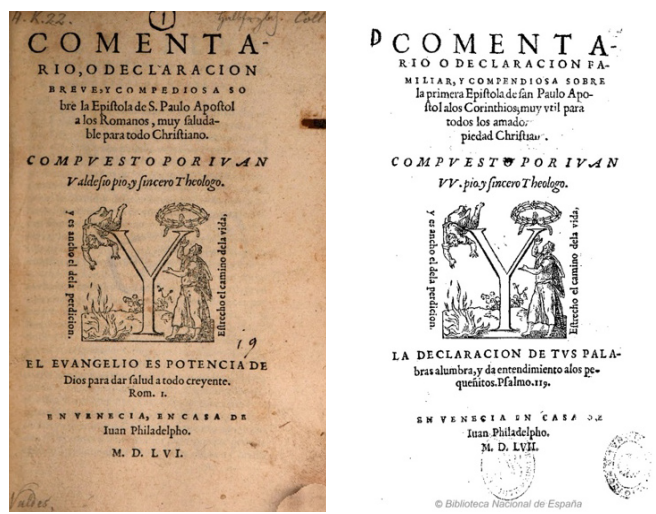

IMÁGENES I4 Y I5. Portadas de las versiones comentadas de Romanos (1556) y 1 Corintios (1557), de Juan de Valdés, impresas por Juan Pérez

cosas escrittas con espiritu santto sean trattadas con mucho respetto». Además, ese respeto queda subrayado, en los lugares en los que las exigencias lingüísticas lo habían obligado a añadir palabras, por el empleo de tinta roja con objeto de diferenciar entre las palabras humanas y las divinas.

Valdés murió pocos meses antes del establecimiento en 1542 de la Inquisición romana, a imitación de la española ${ }^{41}$. El movimiento evangélico formado en torno a él en Nápoles fue a partir de esta fecha perseguido hasta lograr su erradicación. Muchos seguidores de Valdés optaron por el exilio; algunos pasaron a las filas del protestantismo instituido y otros, más radicales, rechazaron toda organización eclesiástica. Quienes creyeron que podían seguir manteniendo una posición de disimulo en tierras italianas acabaron pagando su heterodoxia con la vida.

${ }^{4}$ Paulo III estableció la Inquisición romana en 1542 para luchar contra el avance de la herejía en la península itálica y puso al frente de ella al cardenal Gian Pietro Caraffa, futuro Paulo IV. Respecto a la muerte de Valdés, Menéndez Pelayo escribe, dando la impresión de que lo hace casi con pesar (1992: I, 1139): «Hasta en morirse a tiempo tuvo suerte el propagandista de Cuenca». 
Las obras de Valdés circularon manuscritas por Italia, España y Europa. Las dos epístolas paulinas impresas por Juan Pérez se introdujeron clandestinamente en la península ibérica. Como se ha comentado más arriba, ardieron en la quema de libros llevada a cabo en Valladolid por la Inquisición en 1558.

\section{Francisco de Enzinas}

No se sabe mucho de los primeros años de Francisco de Enzinas (ca. 1520-1552), nacido en el seno de una acomodada familia de comerciantes burgaleses relacionados con Flandes e Inglaterra y con parientes en los Países Bajos (García Pinilla, 2019). Hay constancia de que en 1539 se matriculó en el Colegio Trilingüe de la Universidad de Lovaina, ciudad en la que frecuentó los círculos reformados. Allí, tradujo Breve y compendiosa institución de la religión chistiana (resumen del Catecismus, sive christianae religionis institutio de Calvino) y Tractado de la libertad christiana (traducción del Tractatus de libertate christiana de Lutero), así como los siete salmos penitenciales, textos que en 1541 su hermano Diego (quemado en Roma en 1547) publicó clandestinamente y al parecer sin su permiso (Nelson, en Enzinas, 2008: 50). La obra es una clara afirmación de la justificación por la fe. A pesar del pseudónimo (Francisco de Elao, una hebraización de su apellido) y el falso pie de imprenta (Topeia; al parecer, nombre ficticio de Gante), enseguida se reconoció la autoría de Enzinas, y los hermanos tuvieron que abandonar Lovaina.

Llevado por la admiración a Philip Melanchthon y provisto de diversas cartas de recomendación, Francisco (que usó su apellido traducido a diferentes idiomas: Dryander, Du Chesne, Eichmann, Van Eyck) viajó en 1541 a Wittenberg y se matriculó en la universidad de esa ciudad. Además de tratar a Melanchthon, en cuya casa se alojó y donde tradujo durante el año siguiente el Nuevo Testamento a partir de la edición de Erasmo (Novum Instrumentum), conoció allí a Lutero y otras figuras de la Reforma.

Una vez acabada la traducción del Nuevo Testamento, la publicó a su costa en Amberes (Nuevo Testamento traduzido del Griego a la Lengua Castellana, 1543) y, aprovechando la presencia en Bruselas de Carlos V, a quien la obra está dedicada, le hizo entrega de un ejemplar con la intención de conseguir su aprobación con el libro ya impreso.

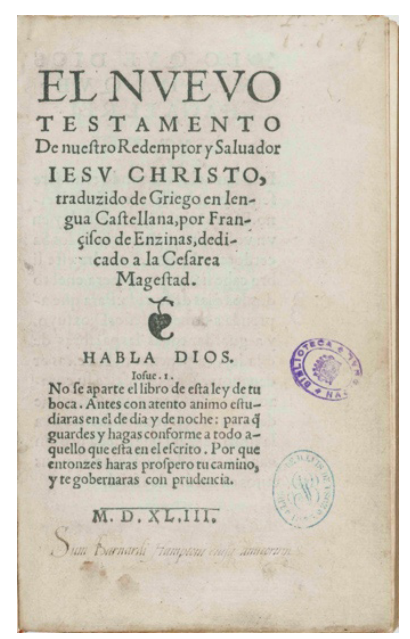

Imagen i6. Portada del Nuevo Testamento (1543), de Francisco de Enzinas

La dedicatoria contiene una defensa de la traducción al vulgar basada en tres razones, en las que incluye una apología de la lengua castellana: el hecho de que es mejor permitirla pues si es contraria a los designios divinos en ningún caso podrá prosperar; la «honra de la nación española», objeto de burla entre las demás al carecer de traducción, siendo además que su «lengua es la mejor (a mi juizio) de las vulgares, o, a lo menos no ay otra mejor»; y, por último, 
46 el hecho de que las herejías no nacen «por ser leydas las sagradas escrituras en lenguas vulgares, sino por ser mal entendidas de muchos, e interpretadas contra la declaraçion y doctrina de la yglesia, que es columna y fundamento de verdad» (Enzinas, 1543).

Sin embargo, Enzinas ya se había significado con su Breve y compendiosa institución. Carlos V delegó la autorización en su confesor, Pedro de Soto. Este, además de la traducción en sí, reprobó la impresión en mayúsculas de unas palabras defendiendo la justificación por la fe (en Romanos, $3: 22$ y $3: 28$ ). Enzinas fue detenido inmediatamente, nada más pisar la calle tras la entrevista, $y$ encarcelado, aunque no fue entregado a la Inquisición española. Logró huir catorce meses más tarde. Vivió desde entonces en un estado de fuga permanente. Se estableció un tiempo en Basilea, donde ejerció de impresor y publicó ediciones de autores clásicos y modernos. Ante su situación incierta en la ciudad debido a la presencia de agentes imperiales, viajó a Inglaterra, donde vivió un tiempo, aunque a fines de 1459 regresó a Basilea, dispuesto a seguir con sus planes de traducción e impresión de los textos bíblicos. Sin embargo, en 1550, la prohibición de publicar en esa ciudad libros que no estuvieran en latín, griego, hebreo y alemán lo llevó a dejarla y a establecerse en Estrasburgo. Allí publicó ese año, cuatro libros del Antiguo Testamento traducidos a partir de la versión latina de Castellio (Salmos, Job, Proverbios, Eclesiástico) con pie de imprenta falso (Sebastian Gryphus, Lyon) (Gilly, 2005: 310) ${ }^{42}$.

\footnotetext{
$4^{2}$ En una carta fechada el 8 de agosto de 1500, Castellio le agradece desde Basilea el envío del Salterio, traducido a partir de su versión latina (Enzinas, 1995: 585). Castellio había concluido su versión latina en 1549, había publicado los Salmos en 1547, pero la Biblia completa vería la luz en 1551 (García Pinilla, en Enzinas, 2017: 15-21).
}

Murió en esa ciudad a finales de 1552, víctima de la peste y sin haber podido concluir la obra con la que, según su última carta (a Calvino), 1levaba «bregando quince años ya» (Enzinas, 1995: 637): la traducción y edición de toda la Biblia en castellano. Esa posible versión completa se perdió tras su muerte junto con otros papeles suyos. Los cuatro libros que logró publicar en vida, el único vestigio de su ambicioso proyecto bíblico, han sido objeto de una edición reciente a cargo de Alba María Caballero Bravo, Sabiduría de lo alto (Enzinas, 2017).

De su Nuevo Testamento Bataillon afirmó que «su influencia sobre la reforma española fue nula» (Bataillon, 1966: 551). Sin embargo, eso no fue del todo así.

\section{Juan Pérez de Pineda}

Sobre la figura de Juan Pérez (ca. 1500-1567) ha existido cierta controversia, puesto que se ha discutido si eran la misma dos personas con idéntico nombre, un diplomático y un clérigo. Aunque Menéndez Pelayo lo negó (1992: 127-128), parece existir un consenso actual acerca de la identidad de ambos personajes: el clérigo secretario de la embajada de la monarquía hispánica en Roma en la segunda mitad de la década de 1520 fue el mismo que dirigió en la década siguiente el orfanato Colegio de Niños de la Doctrina de Sevilla. En esa ciudad tuvo contacto con las ideas luteranas difundidas por Juan Gil, llamado doctor Egidio (a partir de una latinización del apellido), Constantino Ponce de la Fuente, ambos de origen converso, y Francisco de Vargas. Cuando la Inquisición, dirigida por Fernando de Valdés (nombrado arzobispo de Sevilla en 1546 e inquisidor general en 1547), empezó a interesarse por ese círculo en 1549, Juan Pérez huyó a París en 
torno a 1550 (Kinder, 1986: 36), antes de que la Inquisición condenara a Egidio en $1552^{43}$.

Establecido en Ginebra a principios de la década de 1550, no tardó en granjearse la confianza de Teodoro Beza y Calvino y años más tarde sería autorizado a crear una congregación con los correligionarios españoles establecidos en la ciudad. Gordon Kinder (1976: 37) recoge que, según se decía, era el único español en contar con la plena confianza de las autoridades de la ciudad ${ }^{44}$. Desempeñó un activo papel como difusor en castellano de las ideas calvinistas ${ }^{45}$.

En 1556 publicó su versión del Nuevo Testamento y la traducción de Romanos de Juan de Valdés, impresos por Jean Crespin, pero con pie de imprenta falso (Venecia, Juan Philadelpho). En 1557, publicó la traducción de 1 Corintios de Valdés, de nuevo con un pie de imprenta que afirmaba que se publicaba en Venecia por Juan Philadelpho, así como una versión firmada por él de los Salmos, con pie de imprenta igualmente ficticio: Venecia, Pedro Daniel. En el caso de las cartas paulinas de Valdés, las suyas fueron, a los quince años de su muerte, las primeras ediciones de esas obras.

Menéndez Pelayo elogia su prosa (en especial, de los Salmos), pero no cree que sea el ver-

43 Se trató, para él, de una condena benigna, puesto que lo obligó a una retractación pública y a un año de reclusión. Tres seguidores suyos fueron quemados en efigie en el auto de fe llevado a cabo ese año. La retractación de Egidio fue formal, y tras ella siguió defendiendo en secreto postulados protestantes, como la justificación por la fe y el rechazo al culto de los santos, y difundiendo comentarios y traducciones entre su importante red de seguidores en diversos lugares de la península ibérica (Boeglin, 2018).

44 No parece que Pérez, a diferencia de Casiodoro de Reina (que también huiría unos años más tarde a Ginebra), mostrara demasiados escrúpulos ante la ejecución del antitrinitario Miguel Servet ocurrida en 1553.

45 Como afirma Jonathan Nelson (2019: 365), la «labor literaria de Pérez y otros refugiados sevillanos en París jugó un papel clave en la vida de los grupos protestantes en la $\mathrm{Pe}$ nínsula, en particular Sevilla».

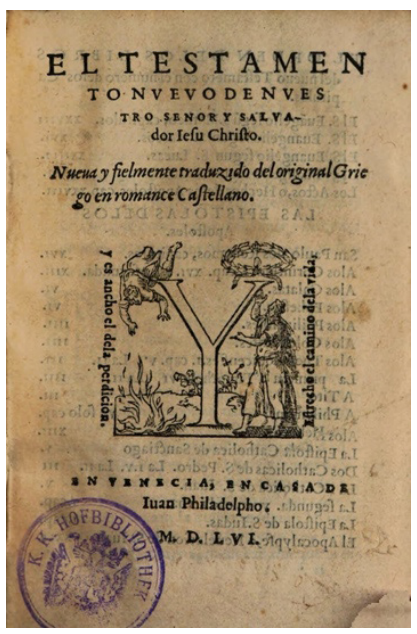

IMAgEN I7. Portada del Nuevo Testamento (1556), de Juan Pérez de Pineda

dadero traductor del Nuevo Testamento ni de los Salmos: «no era tanto hebraizante y helenista de profesión, sino arreglador y propagandista» (1992: 129). El Nuevo Testamento parece ser una revisión de la traducción de Francisco de Enzinas, cuya visión de poner unas Escrituras a disposición del pueblo cristiano Pérez, en palabras de Nelson (2019: 364), «sometió [...] a intereses confesionales y restringidos». Esas dos obras y otras, entre ellas un catecismo compuesto y publicado por el mismo Pérez en 1556, fueron introducidas en España por Julián Hernández, Julianillo, corrector de pruebas en diversas imprentas protestantes europeas, que había huido de Sevilla en 1550, en el momento de la redada inquisitorial contra la llamada «iglesia chiquita» del doctor Egidio. Hernández fue capturado por la Inquisición en 1557 tras un error en la entrega de libros prohibidos en Sevilla (donde uno de sus destinos, entre otros, era el monasterio jerónimo de San Isidoro del Campo). Murió en 
48 la hoguera tres años después en un auto donde también fueron quemados en efigie Juan Pérez, Egidio y Constantino Ponce ${ }^{46}$.

Parece ser que entre 1556 y 1558 Juan Pérez residió en Fráncfort, donde promovió la creación de un fondo para la impresión de la Biblia completa en castellano, que intentaría ser utilizado un tiempo después por Casiodoro de Reina (Kinder, 1986: 46). Más tarde, dejó Ginebra para acompañar como capellán a Renata de Francia, duquesa de Ferrara, vuelta a Francia tras la muerte de Hércules II y establecida en su castillo de Montagris, donde también acogió a Casiodoro de Reina y a su íntimo amigo Antonio del Corro. En 1566, Juan Pérez fue llamado como ministro a Amberes y camino de esa ciudad se detuvo en París para preparar una reedición de su Nuevo Testamento. Allí falleció en octubre de ese mismo año ${ }^{47}$. El Nuevo Testamento se imprimió (o intentó imprimirse) en una imprenta parisina tras su muerte. El proyecto fracasó debido a las maniobras del embajador español en París, Francés de Álava, quien a principios de 1568 logró localizar los ejemplares impresos y destruirlos (Nelson, 2019: 371; Kinder, 1986: 60-61).

\section{Casiodoro de Reina}

Casiodoro de Reina (ca.1520-1594) formó parte de la docena de monjes jerónimos, entre los cua-

\footnotetext{
${ }^{46}$ Egidio había fallecido en 1555. Constantino, que había sido capellán de Carlos I y sucesor de Egidio en la canonjía magistral de Sevilla, fue detenido en 1558 y murió en la cárcel a mediados de 1660. En ambos, sus huesos se desenterraron y se quemaron en el interior de las efigies en el auto de fe llevado a cabo el 22 de diciembre de 1560.

47 1566, interpretando como error la fecha de la carta en la que Antonio del Corro escribe a Renata de Francia refiriéndole la muerte y las últimas voluntades de Pérez: «ce dimanche, 20 d'octobre 1568». Según el calendario juliano, entonces vigente en Francia (lo estaría hasta 1585), el 20 de octubre fue domingo en 1566. Corro se estableció en Londres en 1567 (Nelson, 2019: 370). También Kinder (1986: 59) señala lo extraño de la fecha.
}

les se encontraban también Antonio del Corro y Cipriano de Valera, que huyó del monasterio sevillano de San Isidoro del Campo tras la captura de Julián Hernández en el verano de 1557. Reina inició entonces un periplo en el que no dejaría de moverse por los márgenes de los dominios europeos de Felipe II al tiempo que se dedicaba a trasladar la Biblia cristiana al castellano. En Ginebra, su primer destino, no tardó en sentirse incómodo con la ortodoxia calvinista que imperaba en la ciudad. Condenó públicamente la muerte de Servet, afirmó que la ciudad se había convertido en una nueva Roma y la abandonó (Fernández, 1976: 113). Siguieron entonces diversas estancias, según las circunstancias y la situación política del momento, en Londres, Amberes, Frankfurt, Basilea, Estrasburgo, entre otros lugares, huyendo y escondiéndose siempre de la tupida red de agentes y espías de Felipe II; pero hostigado también por las rencillas doctrinales entre luteranos y calvinistas, cuyos sectores más ortodoxos nunca dejaron de verlo con suspicacia o animadversión. Las inquinas de los círculos calvinistas londinenses, por ejemplo, junto con las maquinaciones del embajador español, motivaron su huida de Londres en 1563. Un año antes, su efigie junto a la de Antonio del Corro, había ardido en un auto de fe celebrado en Sevilla. En 1564 el monarca español pondría precio a su cabeza (Boehmer, 1883: 2, 172).

A pesar de todas las dificultades, pudo concluir la traducción al cabo de diez años y en 1567 inició la búsqueda de un impresor. Tras nuevas peripecias, entre ellas la quiebra y muerte del impresor elegido, Johannes Oporinus ${ }^{48}$, y la pér-

$4^{8}$ Oporinus alcanzó a imprimir otra influyente obra atribuida a Reina y Antonio del Corro, Sanctae Inquisitionis Hispanicae Artes aliquot. Publicada en latín en 1567 (al parecer, a partir de un original en castellano) e inmediatamente traducida a múltiples idiomas. Hay versiones recientes al castellano a cargo de Nicolás Castrillo Benito, El «Reginaldo 
dida del dinero adelantado (procedente, como se ha mencionado, del fondo creado por Juan Pérez en Frankfurt), la obra fue finalmente imprimida en Basilea en 1569 por Thomas Guarin y sin nombre de impresor para facilitar su difusión (Kinder, 1975: 52). De esa primera Biblia cristiana impresa, La Biblia, que es los Sacros Libros del Viejo y Nuevo Testamento, se tiraron 2.600 ejemplares, sufragados por el banquero calvinista Marcus Pérez ${ }^{49}$. Luce en su portada la imagen de un oso rodeado de abejas que intenta alcanzar un panal de miel oculto en el hueco de un árbol, mientras un mazo golpea la hendidura. Esa ilustración ha hecho que la posteridad le haya dado el nombre de Biblia del Oso ${ }^{50}$.

La edición, que incluye notas marginales de tipo filológico o explicativo, se ajusta al canon

Montano»: primer libro polémico contra la Inquisición española (Madrid: CSIC, 1991), y al inglés a cargo de Marcos J. Herráiz, Ignacio J. García Pinilla y Jonathan L. Nelson, Inquisitionis Hispanicae Artes: The Arts of the Spanish Inquisition. Reginaldus Gonsalvius Montanus (Leiden-Boston: Brill, 2018).

49 Marcus Pérez (ca. 1527-1572), un rico comerciante y banquero de familia conversa procedente de Sevilla y convertido al calvinismo. Se había establecido en Basilea tras abandonar Amberes, ante la llegada del duque de Alba en 1568. Pérez utilizaba su amplia red europea de contactos comerciales y familiares para introducir clandestinamente libros prohibidos en la península ibérica. Se ha mencionado la cifra de 30.000 volúmenes de obras calvinistas a mediados de 1566, una cifra sin duda exagerada o errónea, pero sí es cierto que tanto él como su mujer, desempeñaron desde Amberes un importante papel en la impresión y circulación de libros protestantes (Hauben, 1967: 124-125).

$5^{\circ}$ En realidad, esa imagen es un emblema creado por el impresor Matthias Apiarus (Biener), originario de Berna: Biene es abeja en alemán y el oso es el símbolo de Berna. Su hijo Samuel tenía una pequeña imprenta en Basilea y ya no utilizaba la marca tipográfica de su padre. Según Carlos Gilly (1985), Reina se lo pidió o se lo compró porque le gustó la fuerza simbólica de la imagen. En ella, se ha visto el árbol como símbolo de la Iglesia romana que oculta la miel de la palabra de Dios liberada por el mazo de Lutero (Nieto, 1997: 525-526); y también se ha leído el oso como el cristiano sometido a persecución y se ha visto en el mazo que golpea el árbol el esfuerzo del traductor (Alonso Rey, 2012: 59).

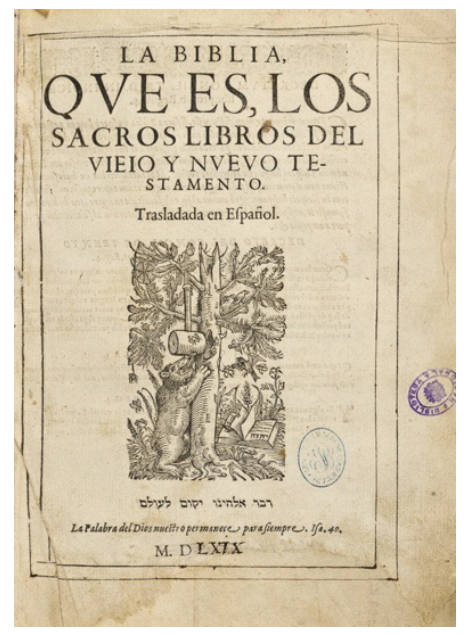

IMAgen i8. Portada de la Biblia del Oso (1569), de Casiodoro de Reina

tradicional cristiano y no omite ni cambia de lugar los libros deuterocanónicos ${ }^{51}$. Fue la primera que introdujo el nombre Jehová («Iehoua»), para referirse a Yahvé. (También introdujo en el castellano algunas palabras como reptil y escultura.)

Casiodoro colocó en el dorso de la portada y antes de su prólogo en latín a todos los príncipes y magistrados de Europa, dos reglas del catálogo de libros prohibidos elaborado tras el Concilio de Trento (Sesión XXV, 1563): la que prohibía las Biblias en vulgar pero concedía a los obispos la facultad muy excepcional de autorizar la lectura a determinados fieles (regla 4); y la que permitía la lectura de versiones anotadas si habían sido aprobadas por las autoridades católicas (regla 3). Con la primera cita, pretendió presentar la restricción tridentina como permiso y, en la segunda, omitió que la autorización se refería a

${ }^{\text {I }}$ Son libros no incluidos en la Biblia hebrea y que no tenían original hebreo. La Reforma no los consideró inspirados y los denominó apócrifos; aunque juzgó que tenían un valor edificante, y en las Biblias protestantes se publicaron, como hizo Lutero, entre los dos Testamentos. 
las versiones expurgadas o de la Vulgata. Trento, además de reconocer la Vulgata como la versión «auténtica» y a la Iglesia católica como su único intérprete, también había prohibido las impresiones anónimas y no autorizadas previamente (Sesión IV, 1546). Casiodoro firmó su prólogo a los príncipes con las siglas C. R. y en su «Amonestación» al lector se definió como «católico», cosa que efectivamente era en su sentido etimológico, pero no en el restrictivo de «romano».

Cuanto a lo que toca al autor de la translación, si católico es el que fiel y sencillamente cree y profesa lo que la santa Madre Iglesia Cristiana Católica cree, tiene y mantiene [...], católico es, e injuria manifiesta le hará quien no lo tuviere por tal ${ }^{52}$.

En ese prólogo al lector, ofrece cuatro razones en defensa de la traducción: prohibirla es «injuria a Dios», «daño de la salud de los hombres» y «obra de Satanás»; «las supersticiones y idolatrías» proceden de la falta de conocimiento de las verdades de la religión; «la Luz y la Verdad [...] à nadie puede engañar ni entenebrecer»; «el estudio de la Divina Palabra es cosa encomendada y mandada de Dios» en los dos Testamentos. Presume de que en ninguna otra versión de las consultadas (salvo en la de Ferrara) hay menos añadiduras con respecto al texto hebreo y explicita su voluntad literalista:

procuramos en nuestra versión toda la claridad que nos fue posible, más de tal manera que el texto quedasse siempre en su enterez reteniendo todas las formas de hablar Hebraicas que o conciertan con las Españolas, como son por la mayor parte, o

\footnotetext{
${ }_{52}$ Semejante afirmación puede considerarse una estrategia de simulación, pero también cabría ver en ella una muestra del escaso valor otorgado por Reina a las rigideces doctrinales: en 1559 había redactado en Londres una confesión de fe calvinista, en 1569 se declaró católico en la «Amonestación» de su Biblia y en 1579 aceptó en Amberes los principios dogmáticos del calvinismo.
}

à lo menos que pueden ser facilmente entendidas, aunque en ello pecassemos algo contra la pulideza de la Española, teniendo por menor mal peccar contra ella, aunque fuesse en mucho, que en muy poco contra la integridad del texto.

Afirma no haber recurrido a la «vieja translación latina, que está en el común uso» (es decir, la Vulgata), porque a pesar de su autoridad se aparta «innumerables vezes de la verdad del texto hebraico»; ese texto hebreo es al que Casiodoro se esfuerza por acercarse «siguiendo comúnmente la translación de Santes Pagnino, que al voto de todos los doctores en la lengua hebrea es tenida por la más pura que hasta ahora hay». Según el cotejo de Constantino Bada (2016: 384), «resulta muy evidente que tiene muy a la vista las traducciones de la Vulgata y de Pagnino, con quienes va coincidiendo según se aproximen o se alejen éstas del texto fuente».

La segunda parte del Nuevo Testamento (después de Hechos) es una simple revisión de la versión de Juan Pérez de Pineda (deudora a su vez de Enzinas), es posible que por falta de tiempo o perdida del manuscrito en la imprenta inicialmente encargada de realizar el trabajo (Bada, 2016: 261-308).

Cabe la posibilidad de que, en la traducción del Antiguo Testamento, Casiodoro utilizara la edición anotada (1542) de Miguel Servet, quien añadió las notas dejadas por Pagnino a su muerte y las amplió. En esa edición, a diferencia de la primera (1528), cada capítulo tiene un encabezamiento con un resumen del contenido, como ocurre en la Biblia del Oso. Según Natalio Fernández y Emilia Fernández, esa Biblia «fue tan innovadora en el siglo XVI como lo fuera la de Jerónimo a finales del siglo IV» (Fernández Marcos y Fernández Tejero, 2003: 327) y, como se ha visto, la traducción de Pagnino se encuentra de algún modo $\mathrm{u}$ otro presente en los esfuerzos de los traductores bíblicos mencionados: dice ser seguida 
en el prólogo introductorio de la Biblia de Ferra$r a$; el debate en Salamanca en torno al permiso de publicación de la edición anotada por Vatablo fue el desencadenante del proceso contra fray Luis de León; Casiodoro de Reina la siguió en su traducción; y fue incorporada a la Biblia regia en versión revisada por Arias Montano para ajustarla más a la literalidad hebrea. En estos dos últimos casos, a partir quizá de la edición de Servet (Kinder, 1975: 55; Nieto, 1997: 531).

Tanto la dedicatoria a todos los dignatarios europeos como la profesión de fe «católica» o la inclusión de los libros considerados «apócrifos» por los protestantes sin cambiarlos de lugar (como hacía también la versión de Pagnino) pueden ser vistas como parte de una estrategia de ocultación y disimulo para poder eludir las censuras inquisitoriales, pero lo cierto es que se corresponden bien con el carácter irenista de Casiodoro y su búsqueda de un texto fijado común; en el caso ideal, en dos versiones, una latina (culta) y otra en vulgar (para el pueblo), a las que se «diesse summa authoridad, para que estas solas tuviessen fuerça de Escritura canonica, por la qual se decidiesse diffinitivamente, como por legitimas leyes, todo negocio o disputa Ecclesiastica». Ahora bien, ese impulso «católico»y poco dado a las disputas sectarias, muy influido por las ideas de tolerancia de Castellio, hizo que su obra no fuera apreciada ni por la ortodoxia católica ni por un importante sector de la disidencia protestante.

El libro se intentó introducir clandestinamente en España. Hay constancia de un envío en 1581 de 1.400 ejemplares de Frankfurt a Amberes, donde se les cambió la portada (por la del diccionario de Ambrogio Calepino) para eludir mejor el control de la Inquisición; de todos modos, la principal difusión tuvo lugar fuera de la jurisdicción de la monarquía hispánica. Otros ejemplares quedaron en poder de los descendientes de Casiodoro, quienes en años posteriores realizaron «actualizaciones» de la obra cambiando la portada y el pie de imprenta (Frankfurt, 1602, 1603 y 1622).

\section{Cipriano de Valera}

Cipriano de Valera (ca.1531-ca.1606) fue uno de los monjes jerónimos que huyeron en 1557 de Sevilla, donde compartió estudios en su juventud con Arias Montano. En realidad, la vida de Valera ofrece un curioso contrapunto a la de Reina: mientras que el segundo llevó una vida errante en lo geográfico y difusa en lo doctrinal en la medida en que se movió en una franja de indeterminación entre el calvinismo y el luteranismo, el primero (tras una breve estancia en Ginebra, como Reina tras huir de Sevilla) fijó su residencia en Inglaterra (de la que apenas salió) y no se movió de unas firmes convicciones calvinistas. En Inglaterra, publicó numerosas obras de propaganda calvinista (Menéndez Pelayo señaló que «en nuestros tiempos hubiera sido periodista de mucho crédito» (1992: 170)) e imprimió en 1596, dos años después de la muerte de Casiodoro, una versión revisada de su Nuevo Testamento. En ella eliminó y añadió notas y realizó algunas modificaciones textuales, aunque sin mención alguna de la autoría original. Como escribió Juan Antonio Pellicer y Saforcada (1778: 44), «en este Testamento no tuvo más parte Valera, que solicitar su publicación, pues es el de Casiodoro de Reyna, de donde le copió este Editor sin declararlo». En 1602, Valera completó su revisión de la obra de Reina con una edición de toda la Biblia, que imprimió Lorenzo Jacobi en Ámsterdam y que recibiría el apelativo de Biblia del Cántaro por un cántaro que aparece como marca del impresor.

En el prólogo, Valera hace una exhortación al estudio de las Escrituras y defiende su traslado a las lenguas vulgares. Cita distintas versiones vernáculas realizadas a lo largo de la historia 
52

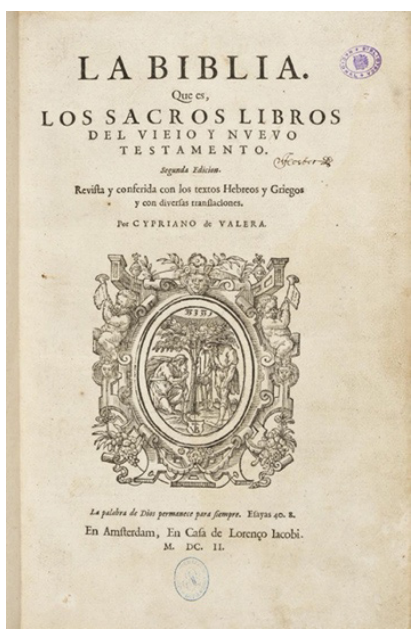

IMAGEN I9. Portada de la Biblia del Cántaro (1602), firmada por Cipriano de Valera

como ejemplo del impulso hacia la traducción consustancial al cristianismo desde sus inicios; entre ellas, menciona la versión árabe hoy perdida realizada en el siglo Ix por Juan Hispalense, obispo de Sevilla (López Guix, 2013). De modo más contemporáneo, cita la Biblia valenciana, la Biblia de Ferrara, los Nuevos Testamentos de Francisco de Enzinas y de Juan Pérez, así como la Biblia de Casiodoro de Reina. Sin embargo, presenta su versión como continuadora de las Biblias políglotas de Cisneros y Arias Montano, empresas multilingües a las que dedica grandes elogios, reivindica para la causa de la difusión de la palabra de Dios y con las que (aunque en un ámbito lingüístico más reducido) considera que entronca su traducción: «Veys aqui Españoles, como nuestros Españoles han encendido dos torchas de luz evangélica, que alumbran à todo el mundo: Y ahora otro vuestro Español enciende la tercera; la qual, ya que no alumbrarà á todo el mundo, por lo menos alumbrará à nuestra España». Tras ello, menciona que su versión es una revisión, en la que ha empleado veinte años, de la traducción de Casiodoro de Reina, a quien sí menciona en esa segunda utilización de su obra y cuyo prólogo original incluye a continuación.

Los veinte años empleados en preparar la $\mathrm{Bi}$ blia fueron juzgados por Menéndez Pelayo (1992: 176) como «ponderación e hipérbole andaluza». La revisión consistió en pequeñas modificaciones al texto de Reina; básicamente, la eliminación de pasajes procedentes de la Septuaginta y la Vulgata (sobre todo, en Proverbios), el cambio de posición de los libros deuterocanónicos (colocados al final del Antiguo Testamento) y la eliminación de toda referencia a ellos en las notas, así como la adición de algunas notas propias. El Nuevo Testamento no es exactamente el publicado en 1596, sino que contiene ligeros retoques; por separado, se publicaría de nuevo en Amsterdam en 1625.

En el prólogo, Valera justifica su trabajo alegando que la edición de Reina era ya difícil de conseguir, algo que no parecer ser del todo cierto teniendo en cuenta la existencia, como se ha mencionado, de ejemplares con nuevas portadas que llevan fecha de ese mismo año y de otros posteriores. Por ello, lo más probable es que la verdadera razón de su labor fuera la calvinización de la obra de Reina ${ }^{53}$.

Esa versión, bautizada como Reina-Valera, ha sido la que ha ganado fama póstuma, puesto que se ha convertido en la Biblia de referencia de las comunidades protestantes hispanas. De todos modos, ese proceso de difusión no cobró importancia hasta mediados del siglo XIX (Nieto, 1997: 535): las sociedades bíblicas protestantes británi-

53 A los pocos años de su publicación, en 1610, fue utilizada por los revisores de la Biblia del rey Jacobo en la fase final de corrección de esa Biblia que sería publicada al año siguiente. Además de usar la Reina-Valera, los revisores cotejaron el texto inglés con la francesa Biblia de Olivétan (1535), la italiana Biblia Diodati (1607), la alemana de Lutero (1534) y dos versiones contemporáneas latinas (Campbell, 2010: 62). 
cas y estadounidenses utilizaron en sus misiones a España Biblias católicas, como la de Scío que introdujo George Borrow. En 1861, la Sociedad Bíblica Británica y Extranjera imprimió en Londres por primera vez la Biblia de Reina-Valera atribuyéndola únicamente a Cipriano de Valera. En las siguientes dos décadas hubo una veintena de ediciones impresas en Oxford, Londres, Madrid, Barcelona y Nueva York. La primera edición que menciona a Casiodoro de Reina como autor es la publicada en 1882 en Barcelona por la Sociedad Bíblica Trinitaria (Boehmer, 1883: 2, 248-256). A lo largo del siglo xx, las diferentes denominaciones protestantes editaron la Biblia de Reina-Valera en múltiples ocasiones, ya sea como Biblia completa o de modo parcial, en un constante proceso de revisión y actualización que no ha cesado con el cambio de siglo, en el que cabe contar una decena de revisiones. La más reciente es la publicada por la Sociedad Bíblica de España en 2020.

\section{CONCLUSIÓN}

Del siglo XVI se ha dicho que fue «el siglo de los traductores de la Biblia» (Fernández Marcos, 2016: 235); sin embargo, fue también un siglo de prohibiciones y persecuciones de humanistas y traductores bíblicos. El clima de intolerancia y persecución intelectual no fue una característica hispana: en la hoguera ardieron Louis de Berquin en París (1529), William Tyndale en Vilvoorde (1536), Étienne Dolet en París (1546), Miguel Servet en Ginebra (1553) o Giordano Bruno en Roma (1600).

Estas páginas han intentado esbozar un somero recorrido por los esfuerzos de traducción bíblica al castellano llevados a cabo a lo largo del siglo XVI en el seno de tres confesiones, desde la Biblia políglota complutense, pasando por la Biblia de Ferrara, hasta la Biblia de Reina-Valera. La primera citada se enmarcó en un grandioso proyecto de regeneración cristiana patrocinado por el cardenal Cisneros, un proyecto que incluyó la creación de una universidad destinada a la formación y reforma del clero. Se concibió como un monumento textual que fijara el texto de las Sagradas Escrituras y que sirviera de base para su estudio. Al igual que la posterior Biblia de Amberes, ilustra un corsé doctrinal que no se atrevió a alejarse de una traducción, la Vulgata, envuelta del aura de una autoridad acumulada a lo largo de un milenio. En cierto modo y como cabe apreciar en la descripción de las obras, los dos proyectos sepultaron bajo un mausoleo de erudición el nuevo espíritu que recorría Europa y que pretendía poner (y ponía) los textos bíblicos al alcance del pueblo, traducidos a su propia lengua cotidiana. En ambos casos, lo más vernáculo está escrito en el mármol del latín y en el pórfido del arameo y el siríaco.

El impulso al cierre de la interpretación plasmado en el rechazo a la traducción se complementó con la represión de lo percibido como disidencia, y se percibió como disidencia todo lo que no era acatamiento. Quienes se atrevieron a disentir del cristianismo oficial solo tuvieron tres opciones: la huida, el silencio o la hoguera. La traducción de la Biblia al castellano a lo largo de todo el siglo se hizo fuera del alcance del poderoso aparato represor del Imperio hispánico, que se extendía más allá de sus fronteras nominales a través de una eficaz red europea de agentes y espías. A pesar de ello, hubo dentro de la península alguna circulación «subterránea», como ponen de manifiesto, por ejemplo, las incautaciones de obras producidas por Pérez de Pineda o la utilización de materiales judíos por parte de fray Luis de León o incluso Quevedo.

En el ámbito judío, la Biblia de Ferrara fue una influyente obra que, además de culminar en cierto modo, una tradición exegética peninsular, y ser utilizada por los judíos sefardíes en su diáspo- 
ra europea, sirvió también de base exegética para las versiones realizadas en el seno del cristianismo. Marcel Bataillon señaló el importante papel de los descendientes de conversos en la vida espiritual española del siglo XVI. Les atribuyó el vigor las nuevas ideas alumbradas y también de las erasmianas $^{54}$. La relación de los intelectuales que participaron a lo largo del siglo XVI en la traducción y difusión de la Biblia en castellano, a pesar de todas las dificultades encontradas (en ocasiones insuperables), pone de manifiesto la importancia en ese esfuerzo de los cristianos nuevos procedentes del judaísmo. Lo fueron todos los hebraístas de la Complutense, así como Juan de Vergara $^{55}$ y Antonio de Nebrija, Arias Montano, fray Luis de León y Juan de Valdés. No parece que sea así en el caso de Francisco de Enzinas ${ }^{56}$, Juan Pérez, Casiodoro de Reina ${ }^{57}$ ni Cipriano de Valera; pero, en relación con los monjes de San Isidoro, cabe recordar que si bien, la orden de San Jerónimo fue la primera en exigir (en 1504) la limpie-

\footnotetext{
54 Bataillon escribió a propósito de la importancia de los conversos en el movimiento alumbrado: «El iluminismo, que será el enemigo íntimo de la ortodoxia española durante todo el siglo XVI, no es monopolio de esos conversos, pero tiene entre ellos algunos de sus más activos propagadores» (Bataillon, 1966: 61). Y también de su aportación al movimiento erasmista: «Si el injerto erasmiano prendió tan bien en el tronco español, se lo debe a esa savia» (Bataillon, 1966: 804).

55 Ha sido considerado cristiano nuevo por muchos autores; entre ellos, Michel Bataillon (1966: 180) o Joseph Pérez (2014: 263). $M^{a}$ del Carmen Vaquero (2019) ha rastreado e identificado los componentes de los árboles genealógicos paterno y materno.

${ }^{5}$ Carlos Gilly (citado en Bergua, 2006: 32) lo considera de ascendencia judía. José Matezanz (2019) y García Pinilla (2019) mencionan su linaje hidalgo, aunque García Pinilla menciona la reserva con la que hay que interpretar los documentos («la manipulación de la genealogía era especialmente notoria en el caso de Burgos», p. 92).

57 A Casiodoro de Reina lo tildó Menéndez Pelayo (1992: II, 138) de «morisco granadino», repitiendo una fórmula del secretario de la embajada española en Londres. No se han hallado pruebas concluyentes al respecto.
}

za de sangre para ingresar en ella, justamente la rama que se estableció en Santiponce se caracterizó por no discriminar a los cristianos nuevos. No es aventurado por ello afirmar que la traducción de la Biblia al castellano en el XVI supuso un esfuerzo ímprobo realizado contra la ortodoxia y el poder establecido desde la extraterritorialidad no solo del Imperio sino también, en buena medida, de la pureza de sangre.

\section{Nota}

Deseo agradecer a Javier Pérez Escohotado sus comentarios y sugerencias en relación con algunos aspectos del movimiento alumbrado y su influencia. También deseo dar las gracias a los revisores anónimos que leyeron el texto y aportaron ideas para introducir matices y mejoras.

\section{REFERENCIAS BIBLIOGRÁFICAS}

Agten, Els (2018): «Las traducciones de la Biblia al castellano y la Reforma. Una empresa transfronteriza», en Michel Boeglin, Ignasi Fernández Terricabras y David Kahn (eds.), Reforma y disidencia religiosa, Madrid: Casa de Velázquez, 95-110, $<$ https://books.openedition.org/cvz/5657>. [consulta: 1 octubre 2020].

Alcalá, Ángel (ed.) (1991): Proceso inquisitorial de fray Luis de León, Salamanca: Junta de Castilla y León.

Alonso SCHÖKEL, Luis, y Eduardo ZuRro (1977): La traducción bíblica: lingüistica y estilística, Madrid: Cristiandad.

Alonso Rey, María Dolores (2012): «Los emblemas de las Biblia del Oso y del Cántaro. Hipótesis interpretativa», IMAGO. Revista de Emblemática y Cultura Visual, 4, 55-61.

Amigo EspadA, Lorenzo (1990): «Biblias en romance y Biblias en ladino: evolución de un sistema de traducción», Ciudad de Dios. Revista agustiana, 203/1, 111-142.

AvenozA, Gemma (2008): «Las traducciones de la Biblia en castellano en la Edad Media y sus comen- 
tarios», en Gregorio del Olmo Lete (ed.), La Biblia en la literatura española, I/2 Edad Media. El texto: fuente y autoridad, coord. María Isabel Toro Pascua, Madrid: Trotta, 13-75.

Bada Prendes, Constantino (2016): La Biblia del Oso de Casiodoro de Reina; primera traducción completa de la Biblia al castellano, tesis doctoral, Salamanca: Universidad de Salamanca, <https://summa.upsa.es/ viewer.vm?id=49131>. [consulta: 1 octubre 2020].

BÁdenas de la PeÑa, Pedro, y Shifrea Sznol (2013): «Las traducciones en ladino y en judeo-griego en el Pentateuco de Constantinopla», Erytheia, 34, 121137, <http://digital.csic.es/handle/10261/192162>. [consulta: 1 octubre 2020].

BAtAillon, Marcel $\left(1966^{2}\right)$ : Erasmo y España: estudios sobre la historia espiritual del siglo XVI, trad. Antonio Alatorre, México-Buenos Aires: Fondo de Cultura Ecuménica.

Becerra Hiraldo, José María (2003): El Cantar de los Cantares de Salomón. Interpretaciones literal y espiritual, Madrid: Cátedra.

Bergua CAVERo, Jorge (2006): Francisco de Enzinas. Un humanista reformado en la Europa de Carlos V, Madrid: Trotta.

Boeglin, Michel (2018): «El doctor Egidio y la Reforma en Sevilla. Redes y proselitismo religioso», en Michel Boeglin, Ignasi Fernández Terricabras y David Kahn, Reforma y disidencia religiosa. La recepción de las doctrinas reformadas en la península ibérica en el siglo XVI, Madrid: Casa de Velázquez.

BoEHMER, Edward (1883): Bibliotheca Wiffeniana: Spanish Reformers of Two Centuries from 1520, vol. 2, Estrasburgo-Londres:Trübner, $<$ https://archive. org/details/bibliothecawiffoowiffgoog/page/n6/ mode/2up > . [consulta: 1 octubre 2020].

BoER, Harm der (1994): «La Biblia de Ferrara y otras traducciones españolas de la Biblia entre los sefardíes de origen converso», en Iacob M. Hassán, Introducción a la Biblia de Ferrara. Actas del simposio internacional, Sevilla, noviembre de 1991, Madrid: Sociedad Estatal Quinto Centenario, 251-296.

BujANDA, Jesús M. de (1984): «El primer "Índice de libros prohibidos"», Scripta Theologica, 16/1-2, 443450, <https://core.ac.uk/download/pdf/83565606. pdf $>$. [consulta: 1 octubre 2020].
Bunis, David M. (1994): «Tres formas de ladinar la Biblia en Italia en los siglos XVI-XVII», en Iacob M. Hassán, Introducción a la Biblia de Ferrara. Actas del simposio internacional, Sevilla, noviembre de 1991, Madrid: Sociedad Estatal Quinto Centenario, 315-345.

CABANAL Rodríguez, Laura (2001): «Heterodoxia en el reinado del Emperador: Toledo, los alumbrados e Isabel de la Cruz», en José Martínez Millán (ed.), Carlos Vy la quiebra del humanismo político en Europa (1530-1558), vol. 4 (Jesús Bravo Lozano, Carlos Javier de Carlos Morales, ed.), Madrid: Sociedad Estatal para la Conmemoración de los Centenarios de Felipe II y Carlos V, 309-332.

CAmpbell, Gordon (2010): Bible. The Story of the King James version 1611-2011, Oxford-Nueva York, Oxford University Press.

CArbajosa, Ignacio (2014): «A los 500 años de la Biblia Políglota Complutense. Enseñanzas de un gran proyecto editorial», en Ignacio Carbajosa y Andrés García Serrano (eds.), Una Biblia a varias voces. Estudio textual de la Biblia Políglota Complutense, Madrid: Universidad San Dámaso, 7-31.

CARBAJOSA, Ignacio (2016): «La confluencia de las exégesis judía y cristiana en la Biblia Políglota Complutense», en Antonio Alvar Ezquerra (ed.), La Biblia Políglota en su contexto, Alcalá de Henares: Universidad de Alcalá, 105-115.

CASTRILlo Benito, Nicolás (1991): El «Reginaldo Montano»: primer libro polémico contra la Inquisición española, Madrid: CSIC.

CoHEN, Dov (2019): «Novedades bibliográficas en el estudio de las ediciones de biblias sefardíes (siglo XVI)», Sefarad, 79/1, 199-224), <https://dialnet.unirioja.es/servlet/articulo?codigo $=7012900>$. [consulta: 1 octubre 2020].

Domínguez Domínguez, Juan Francisco (2015): «Arias Montano y Guillaume Postel», Studia Philologica Valentina, 17, 139-158.

DUNKELGRÜN, Theodor W. (2012): The Multiplicity of Scripture: The Confluence of Textual Traditions in the Making of the Antwerp Polyglot Bible, 1568-1573, tesis doctoral, Chicago: University of Chicago.

Eco, Umberto (1994): La búsqueda de la lengua perfecta, trad. María Pons, Barcelona: Crítica. 
ENRIQUe-Arias, Andrés, y F. Javier Pueyo Mena (2017): «La Biblia completa del Marqués de Santillana». Revista de Filología Española, 97/1, 35-68.

EnzinAs, Francisco de (1995): Epistolario, ed. crít. Ignacio J. García Pinilla, Ginebra: Droz.

EnZINAS, Francisco de (2008): Breve y compendiosa institución de la religión cristiana, ed. Jonathan L. Nelson, Cuenca: Ediciones de la Universidad de Castilla-La Mancha, <https://books.google.es/ books?id=2hFXYc_xtVsC $>$. [consulta: 1 octubre 2020].

EnZINAS, Francisco de (2017): Sabiduría de lo alto. Cuatro traducciones bíblicas del siglo XVI, ed. y glosario Alba María Caballero Bravo, intr. Ignacio J. García Pinilla, Cuenca: Ediciones de la Universidad de Castilla-La Mancha.

FernándeZ y Fernández, Enrique (1976): Las Biblias castellanas del exilio, Miami: Florida.

FERNÁNDEZ LóPEZ, Sergio (2003): Lectura y prohibición de la Biblia en lengua vulgar. Defensores y detractores, León: Universidad de León.

FernáNDEZ López, Sergio (2007): «El Cantar de los Cantares de fray Luis. ¿Una traducción original?», Bulletin Hispanique, 109, <17-45. https://journals.openedition.org/bulletinhispanique/82>. [consulta: 1 octubre 2020].

FERNÁNDEZ LóPeZ, Sergio (2009): El Cantar de los Cantares en el Humanismo español. La tradición judía, Huelva: Universidad de Huelva, <https://books. google.es/books?id=7CIyDAAAQBAJ>. [consulta: 1 octubre 2020].

FERNÁNDEZ LóPEZ, Sergio (2010): «Del esfuerzo traductor a la despreocupación del copista: la versión del Libro de Job de fray Luis de León», Hispanic Review, 78/3, 345-367.

FERNÁNDEZ LóPEZ, Sergio (2011): «La llamadas Biblias el exilio en España: sobre su difusión en la península ibérica según el testimonio de Pedro Palencia $\mathrm{y}$ otros interrogatorios inquisitoriales», Bibliothèque d'Humanisme et Renaissance, 73, 2, 293-301.

FERNÁNDEZ LóPEZ, Sergio (2020): «Estrategias de persuasión en las versiones bíblicas. El caso de la Biblia de Ferrara», e-Spania, 36.

Fernández Marcos, Natalio (1985): «El Pentateuco griego de Constantinopla», Erytheia. Revista de estudios bizantinos y neogriegos, 6, 2, 185-203.
Fernández Marcos, Natalio (1994): «La Biblia de Ferrara y sus efectos en las traducciones bíblicas al español», en Iacob M. Hassán, Introducción a la Biblia de Ferrara. Actas del simposio internacional, Sevilla, noviembre de 1991, Madrid: Sociedad Estatal Quinto Centenario, pp. 445-471.

FernÁndez Marcos, Natalio (1997): «El texto griego de la Biblia Políglota Complutense», en Natalio Fernández Marcos y Emilia Fernández Tejero, Biblia y humanismo, Madrid: Fundación Universitaria Española, 1997, pp. 219-227.

FernÁndeZ Marcos, Natalio (2002): «¿Quevedo hebraísta? Lágrimas de Hieremías castellanas», Sefarad, 62, pp. 309-328, <http://sefarad.revistas.csic. es/index.php/sefarad/article/view/560>. [consulta: 1 octubre 2020].

FernÁNdez Marcos, Natalio (2012): «Políglotas y versiones: luces y sombras del biblismo español del siglo XVI», en Filología bíblica y humanismo, Madrid: CSIC.

FernándeZ Marcos, Natalio (2016): «La Políglota Complutense en su contexto», en Antonio Alvar Ezquerra (coord.), La Biblia Políglota en su contexto, Alcalá de Henares: Universidad de Alcalá, 231-238.

Fernández Marcos, Natalio y Emilia Fernández TeJERo (2003): «Pagnino, Servet y Arias Montano. Avatares de una traducción latina de la Biblia Hebrea», Sefarad, 63, 283-329, <http://hdl.handle. net/10261/19084>. [consulta: 1 octubre 2020].

FrançoIs, Wim (2018): «Vernacular Bible Reading in Late Medieval and Early Modern Europe: The "Catholic" Position Revisited», The Catholic Historical Review, 104/1, 23-56, <https://lirias.kuleuven. be/retrieve/567000>. [consulta: 1 octubre 2020].

García Pinilla, Ignacio Javier. (2016): «La influencia de la Biblia Políglota Complutense», en Antonio Alvar Ezquerra (ed.), La Biblia Políglota en su contexto, Alcalá de Henares: Universidad de Alcalá, 327-336.

García Pinilla, Ignacio Javier. (2019): «Francisco Enzinas, el hijo del mercader en un mundo de influencias», en Cristina Borreguero Beltrán y Asunción Retortillo Atienza (eds.), La memoria de un hombre. El burgalés Francisco de Enzinas en el $V$ centenario de la Reforma protestante, Burgos: Universidad de Burgos, 89-113. 
García Pinilla, Ignacio Javier. (2020): «The Debate Surrounding Lay Bible Reading in Spain in the Sixteenth-Century», en Erminia Ardissino y Élise Boillet (eds.), Lay Readings of the Bible in Early Modern Europe, Leiden-Boston: Brill, 65-85.

GARCía-VillosLADA, Ricardo (2016): Martín Lutero. El fraile hambriento de dios, t. 1, Madrid: Biblioteca de Autores Cristianos.

Gil Fernández, Luis (1997): Panorama social del humanismo español (1500-1800), Madrid: Tecnos.

GILly, Carlos (1982): «Juan de Valdés, traductor y adaptador de escritos de Lutero en su Diálogo de doctrina christiana», en Luis López Molina (coord.), Miscelánea de estudios hispánicos. Homenaje de los hispanistas de Suiza a Ramon Sugranyes de Franch, Montserrat: Abadia de Montserrat.

GiLly, Carlos (1985): «Defensa de Casiodoro», en Historia de la Biblia en español, recurso online, <https:// medium.com/historia-de-la-biblia-en-espanol/ historia-de-la-biblia-de-casiodoro-de-reina7 fca 84 bd10bd $>$. [consulta: 1 octubre 2020].

GILLY, Carlos (2005): «Erasmo, la reforma radical y los heterodoxos radicales españoles», en Tomàs Martínez Romero (ed.), Les lletres hispàniques al segles XVI, XVII $i$ XVIII, Castellón de la Plana: Universitat Jaume I, 225-376, <https://www.academia.edu/34598615/ Erasmo_la_reforma_radical_y_los_heterodoxos_radicales_españoles $>$. [consulta: 1 octubre 2020].

GonZÁlez CARVAJAL, Tomás (1832): Elogio histórico del Doctor Benito Arias Montano, Madrid: Academia de la Historia, <https://babel.hathitrust.org/cgi/pt?i $\mathrm{d}=w u .89070495965 \&$ view $=1$ up\&seq $=150>$. [consulta: 1 octubre 2020].

GRAFTON, Anthony (2020): La cultura de la corrección de textos en el Renacimiento, trad. Emilia Ghelfi, Bogotá-Buenos Aires: Universidad de los Andes/ Ampersand.

Hassán, Iacob M. (1994): «Dos introducciones de la Biblia de Ferrara», en Iacob M. Hassán, Introducción a la Biblia de Ferrara. Actas del simposio internacional, Sevilla, noviembre de 1991, Madrid: Sociedad Estatal Quinto Centenario, 13-66.

Hauben, Paul J. (1967) : «Marcus Pérez and Marranos Calvinism in the Dutch Revolt and Reformation», Bibliothèque d'Humanisme et Renaissance, 29/1, 121-132.
Hefele, Karl Joseph von (1869): El cardenal Jiménez de Cisneros y la Iglesia a fines del siglo xV y principios del XVI, trad. anónima del francés, Barcelona: Imprenta del Diario de Barcelona, <https://books.google. com.ec/books?hl=es\&id=2xiuOj0N_9AC\&pg= PA90>. [consulta: 1 octubre 2020].

Herraiz, Marcos J., Ignacio J. García Pinilla y Jonathan L. Nelson (2018): Inquisitionis Hispanicae Artes: The Arts of the Spanish Inquisition. Reginaldus Gonsalvius Montanus, Leiden-Boston: Brill.

JIMÉNEZ CALVENTE, Teresa (2016): «Quidam heres stupidusque manes? La Biblia en manos de los grammatici: Antonio de Nebrija y otros eruditos complutenses», en Antono Alvar Ezquerra (coord.), La Biblia Políglota en su contexto, Alcalá de Henares: Universidad de Alcalá, 239-260.

JimÉNEZ Monteserín, Miguel (2013): «Juan de Valdés (1495?-1541)», en Ignacio J. García Pinilla (coord.), Disidencia religiosa en Castilla la Nueva en el siglo XVI, Toledo: Almud, 131-157.

KINDER, A. Gordon (1975): Casiodoro de Reina. Spanish Reformer of the Sixteenth Century, Londres, Tamesis Books.

Kinder, A. Gordon (1986): «Juan Pérez de Pineda (Pierius): un ministro calvinista español del evangelio en el siglo XVI en Ginebra», Diálogo Ecuménico, 21/69, 31-64. (Es traducción con una ligera ampliación de «Juan Pérez de Pineda (Pierius): a Spanish Calvinist minister of the Gospel in sixteenthcentury Geneva», Bulletin of Hispanic Studies, 53 (1976), 283-300).

LAPESA, Rafael $\left(1981^{\circ}\right)$ : Historia de la lengua española, Madrid: Gredos.

LitTLEFIELD, Mark G. (ed.) (1983): Escorial Bible I.I.8, Madison: Hispanic Seminary of Medieval Studies.

LAZAR, Moshe (1994): «Ladinando la Biblia entre los sefardíes mediterráneos: Italia, Imperio otomano y Viena», en Iacob M. Hassán, Introducción a la Biblia de Ferrara. Actas del simposio internacional, Sevilla, noviembre de 1991, Madrid: Sociedad Estatal Quinto Centenario, 347-372.

LEÓN, fray Luis de (1991): Escritos desde la cárcel. Autógrafos del primer proceso inquisitorial, ed. José Barrientos García, San Lorenzo del Escorial: Ediciones Escurialenses, <http://www.cervantesvirtual. 
com/nd/ark:/59851/bmc44645>. [consulta: 1 octubre 2020].

León, fray Luis de (1992): Cantar de los Cantares. Interpretaciones: literal, espiritual, profética, texto bilingüe, trad., intr. y not. José María Becerra Hiraldo, San Lorenzo de El Escorial: Ediciones Escurialenses, <http://www.cervantesvirtual.com/ nd/ark:/59851/bmcm3397>. [consulta: 1 octubre 2020].

LEón, fray Luis de (1994): Cantar de cantares de Salomón, ed. José Manuel Blecua, Madrid: Gredos.

López DE Ayala, Ignacio (17873): El sacrosanto y ecuménico Concilio de Trento, Madrid: Imprenta Real. https://books.google.es/books?id=gtP3Xly2pYwC [consulta: 1 octubre 2020].

LóPEz GuIX, Juan Gabriel (2013): «Las primeras traducciones bíblica en la península ibérica», 1611, 7, $<$ http://www.traduccionliteraria.org/1611/art/lopezguix3.htm>. [consulta: 1 octubre 2020].

MACRÍ, Oreste (1970): La poesía de fray Luis de León, Salamanca: Anaya.

Márquez, Antonio (1972): Los alumbrados. Orígenes y filosofía (1525-1559), Madrid: Taurus. (Hay segunda edición de 1980, corregida y aumentada).

Macías Rosendo, Baldomero (1998): La Biblia Políglota de Amberes en la correspondencia de Benito Arias Montano, Huelva: Universidad de Huelva, $<$ https://ebookcentral.proquest.com/lib/uab/detail.action?docID $=4569758>$. [consulta: 1 octubre 2020].

Macías Rosendo, Baldomero (2013): «El Apparatus sacer en la Biblia Regia», en Benito Arias Montano, Antigüedades hebraicas. Antiquitatium Iudaicarum Libro IX. Tratados exegéticos de la Biblia Regia. Apparatus Sacer, Luis Gómez Canseco y Sergio Fernández López eds, Huelva: Universidad de Huelva, 13-42.

Martín ABAD, Julián (2016): «La impresión y la puesta en venta de la Biblia Políglota Complutense», en Antonio Alvar Ezquerra (coord.), La Biblia Políglota en su contexto, Alcalá de Henares: Universidad de Alcalá, pp. 295-326.

Matesanz del Barrio, José (2019): «El canónigo Pedro de Enzinas y la afirmación de un linaje familiar en el siglo XVI», en Cristina Borreguero Beltrán y
Asunción Retortillo Atienza (coords.), La memoria de un hombre. El burgalés Francisco de Enzinas en el $V$ centenario de la Reforma protestante, Burgos: Universidad de Burgos, pp. 115-131.

Matesanz del Barrio, María (1997): «"Epístolas y Evangelios por todo el año”. Una errónea atribución de autoría», Revista de Filología Románica, 13, <https://revistas.ucm.es/index.php/RFRM/article/ view/RFRM9696110215A/12112>. [consulta: 1 octubre 2020].

Menéndez Pelayo, Ramón (1916): Historia de la poesía castellana en la Edad Media, t. III, Madrid: Librería General de Victoriano Suárez, <https://archive.org/ details/obrascompletas06men>. [consulta: 1 octubre 2020].

Menéndez Pelayo, Ramón (1992): Historia de los heterodoxos españoles, 3 vols., Madrid: CSIC. 1: <https://books.google.es/ books?id=vPi9qQFIR94C>; 2: <https://books. google.es/books?id=IjHNwB4tOSOC>; 3: <https:// books.google.es/books?id=shGc4cPPmL4C $>$. [consulta: 1 octubre 2020].

Meneses García, Emilio (ed.) (1973): Correspondencia del conde de Tendilla, Madrid: Real Academia de la Historia.

Moll, Jaime (1990): «Plantino, los Junta y el "Privilegio” del Nuevo Rezado», en Hans Tromp y Pedro Peira (eds.), Simposio Internacional sobre Cristóbal Plantino (18, 19 y 20 de enero de 1990), Madrid: Universidad Complutense, 1990, pp. 9-23, <http:// www.cervantesvirtual.com/nd/ark:/59851/ bmcc55c0>. [consulta: 1 octubre 2020].

Moll, Jaime (2000): «Amberes y el mundo hispano del libro», en Werner Thomas y Robert A. Verdonk (eds.), Encuentros en Flandes: relaciones e intercambios hispanoflamencos a inicios de la Edad Moderna, Lovaina-Soria: Leuven University Press/Fundación Duques de Soria, 117-132.

Moreno, Doris (2017): Casiodoro de Reina. Libertady tolerancia en la Europa del siglo XVI, Sevilla: Fundación Pública Andaluza Centro de Estudios Andaluces.

Morocho, Gaspar (1987): «Transmisión histórica y valoración actual del biblismo de Arias Montano», Cuadernos de Pensamiento, 12, 135-239, <http:// www.fuesp.com/pdfs_revistas/cp/12/cp-12.pdf > . [consulta: 1 octubre 2020]. 
MuÑoz Solla, Ricardo (2016): «Hermenéutica hebrea y persecución inquisitorial: el caso del hebraísta salmantino Martín Martínez de Cantalapiedra (s. XVI)», Miscelánea de Estudios Árabes y Hebraicos, 65, 59-81 <https://revistaseug.ugr.es/index.php/ meahhebreo/article/view/12392/10457>. [consulta: 1 octubre 2020].

Nelson, Jonathan (2019): «El Nuevo Testamento de Francisco de Enzinas (1543): las peripecias de un texto prohibido», en Cristina Borreguero Beltrán y Asunción Retortillo Atienza (coords.), La memoria de un hombre. El burgalés Francisco de Enzinas en el $V$ centenario de la Reforma protestante, Burgos: Universidad de Burgos, 357-378.

NiETo, José C. (1979): Juan de Valdés y los orígenes de la Reforma en España e Italia, Madrid: Fondo de Cultura Económica.

NiEto, José C. (1997): El Renacimiento y la otra España, Ginebra: Droz, <https://books.google.es/ books?id=lQxnsnj4mIAC>. [consulta: 1 octubre 2020].

Olmo Lete, Gregorio del (2008): «La Biblia en la literatura espiritual del Siglo de Oro», en Gregorio del Olmo Lete (ed.), La Biblia en la literatura española, vol. II. Siglo de Oro, ed. Rosa Navarro, Madrid: Trotta, 101-179.

Pellicer y SAforcada, Juan Antonio (1778): Ensayo de una biblioteca de autores españoles, Madrid: Antonio de Sancha, <http://www.traduccionliteraria.org/ biblib/misc/MS101.pdf>. [consulta: 1 octubre 2020].

Pérez, Joseph (2014): Cisneros, el cardenal de España, Madrid: Taurus.

Pérez Alonso, Ma Isabel (2011): «Las biblias romanceadas medievales o la aventura de traducir la "verdad hebrayca" al castellano», Helmántica, 62, 391-415. <https://dialnet.unirioja.es/servlet/ articulo? codigo $=4404754>$. [consulta: 1 octubre 2020].

Pérez CASTro, Federico (1970): «Biblias políglotas y versiones no españolas», Scripta Theologica, 2, 2, 513-547, <https://hdl.handle.net/10171/12274>. [consulta: 1 octubre 2020].

Portuondo, María M. (2019): The Spanish Disquiet: The Biblical Natural Philosophy of Benito Arias Montano, Chicago-Londres: The Univer- sity of Chicago Press, <https://books.google.es/ books?id=MfCIDwAAQBAJ>. [consulta: 1 octubre 2020].

Proctor, Robert (1900): The Printing of Greek in the Fifteenth Century, Oxford: Oxford University Press, <https://archive.org/details/cu31924029500414>. [consulta: 1 octubre 2020].

RABAEY, Hélène (2015): «La Nueva traslación y interpretación española de los cuatro sacrosantos Evangelios de Jesu Christo de fray Juan de Robles, un alegato a favor de la lectura en lengua vulgar de los Evangelios y la concordia entre cristianos», en José $\mathrm{M}^{\mathrm{a}}$ Maestre, Sandra I. Ramos, Manuel A. Díaz et al. (eds.), Humanismo y pervivencia del mundo clásico. Homenaje al profesor Juan Gil, vol. 2, Alcañiz-Madrid: Instituto de Estudios Humanísticos.

RABAEY, Hélène (2018): «El prólogo a la Nueva traslación y interpretación española de los cuatro sacrosantos Evangelios de Jesu Christo de fray Juan de Robles: edición y estudio», Hispania Sacra, 70, 142, 481494, <https://hispaniasacra.revistas.csic.es/index. php/hispaniasacra/article/view/759/759>. [consulta: 1 octubre 2020].

SÁENZ-BADIllos, Ángel (1995): «En torno a dos comentarios al Cantar de los Cantares», Helmántica, 46, 158-176, <https://summa.upsa.es/high. raw?id=0000003442\&name $=00000001$.original. pdf $>$. [consulta: 1 octubre 2020].

SÁENZ-BADILlos, Ángel (1997): «Benito Arias Montano, hebraísta», Thélème, 12, 345-359.

Salvador Miguel, Nicasio (2016): «Cisneros en Granada y la quema de libros islámicos», en Antonio Alvar Ezquerra (coord.), La Biblia Políglota Complutense en su contexto, Alcalá de Henares: Universidad de Alcalá de Henares.

SÁnCHEZ-CARo, José Manuel (2002). «Intervención de la Iglesia en la labor traductora. El caso de la Biblia en España», Salmanticensis, 49, 387-432.

SÁnChEZ-CARo, José Manuel (2007): «Biblia e Ilustración. Versiones castellanas de la Biblia en el siglo xviII», Helmántica, 58, 397-496, <https:// summa.upsa.es/pdf.vm?id=29409>. [consulta: 1 octubre 2020].

SÁnchez-Prieto Borja, Pedro (2002): «Biblias romanceadas», en Carlos Alvar y José Manuel Lucía Me- 
60 gías (eds.), Diccionario filológico de literatura medieval española, Madrid: Castalia, 2002.

SigüEnZA, José de (1853): Vida de San Gerónimo, doctor máximo de la Iglesia, Madrid: Imprenta de la Esperanza, <https://books.google.es/ books?id=K8W9ryJF1AkC $>$. [consulta: 1 octubre 2020].

SCHWARZWALD, Ora (Rodrigue) (2010): «On the Jewish Nature of Medieval Spanish Biblical Translations. Linguistic Differences between Medieval and Post-Exilic Spanish Translations of the Bible», Sefarad, 70, 1, 117-140, <https://dialnet.unirioja.es/ servlet/articulo?codigo $=3265119>$. [consulta: 1 octubre 2020].

SEGRE, Renata (1994): «Contribución documental a la historia de la imprenta Usque y de su edición de la Biblia», en Iacob M. Hassán, Introducción a la Biblia de Ferrara. Actas del simposio internacional, Sevilla, noviembre de 1991, Madrid: Sociedad Estatal Quinto Centenario, pp. 205-226.

Vaquero Serrano, Ma del Carmen (2019): «La familia de Juan de Vergara, canónigo erasmista toledano», Lemir, 23, 9-96.

WILKInson, Robert J. (2007): The Kabbalistic Scholars of the Antwerp Polyglot Bible, Leiden-Londres: Brill.

WiLliams, George H. (1962): The Radical Reformation, Filadelfia: Westminster Press. 